\author{
RAFAŁ WĄDOLOWSKI \\ ORCID: 0000-0003-0601-1213
}

DOI: $10.4467 / 20801335$ PBW.21.006.13563

\title{
Ochrona tajemnicy państwowej w Federacji Rosyjskiej. Wybrane regulacje karne $i$ administracyjne
}

W związku z brakiem piśmiennictwa poświęconego prawodawstwu, które dotyczyłoby ochrony informacji niejawnych w Federacji Rosyjskiej (dalej: FR), należy uznać za niezbędne chociażby ogólne omówienie systemu ochrony tajemnic państwowych w Rosji. Przedstawienie instytucji prawnych naszego wschodniego sąsiada jest też pretekstem do próby przeprowadzenia analizy porównawczej rozwoju systemu ochrony tajemnic publicznoprawnych w Rzeczpospolitej Polskiej (dalej: RP). Należy nadmienić, że w Polsce odrodzonej w $1918 \mathrm{r}$. kodeks karny był początkowo tożsamy z kodeksem rosyjskim, co było spowodowane przyjęciem tzw. kodeksu Nikołaja Tagancewa z 1903 r. Po II wojnie światowej kilkudziesięcioletnie pozostawanie Polski w strefie wpływów politycznych Związku Radzieckiego przyczyniło się do unifikacji formalnie odrębnych systemów prawnych. Dotyczyło to szczególnie sfery tajemnicy odnoszącej się do potencjalnych działań militarnych $\mathrm{w}$ ramach ówczesnego Układu Warszawskiego oraz podtrzymywania socjalistycznego ustroju państwa. Zmiany polityczne w RP po $1990 \mathrm{r}$. były podstawą ewoluowania systemu prawnego w kierunku demokratycznego państwa prawa, czego wyrazem było przyjęcie Konstytucji RP w 1997 r. ${ }^{1}$ Wstąpienie Polski do NATO (1999 r.) i do Unii Europejskiej (2004 r.) determinowało dostosowanie systemu ochrony informacji niejawnych do standardów obowiązujących w państwach członkowskich tych organizacji, z jednoczesnym uwzględnieniem konstytucyjnego prawa obywateli do informacji publicznej. Tak określona tematyka badawcza implikuje hipotezę, że aktualne systemy ochrony tajemnicy państwowej w Rosji oraz informacji niejawnych w Polsce wykazują istotne różnice.

Konstytucja Rzeczypospolitej Polskiej z dnia 2 kwietnia 1997 r. uchwalona przez Zgromadzenie Narodowe $w$ dniu 2 kwietnia 1997 r., przyjęta przez Naród w referendum konstytucyjnym w dniu 25 maja 1997 r., podpisana przez Prezydenta Rzeczypospolitej Polskiej w dniu 16 lipca 1997 r. (DzU z 1997 r. nr 78 poz. 483). 


\section{Ograniczenie konstytucyjnego prawa do informacji w Federacji Rosyjskiej}

W aktach prawnych ustanawiających system ochrony tajemnic w FR informacje niejawne o najwyższej ważności ze względu na bezpieczeństwo państwa określa się terminem tajemnica państwowa (ros. государственная тайна, pis. fon. gosudarstwiennaja tajna). System ochrony tajemnicy państwowej w Rosji, podobnie jak system ochrony informacji niejawnych w Polsce, jest oparty na dwóch filarach: karnoprawnym i administracyjnym. Rosyjskie tajemnice państwowe są informacjami klauzulowany$\mathrm{mi}$, a ich odpowiednikiem w polskim prawodawstwie są informacje chronione na podstawie ustawy z 5 sierpnia 2010 r. o ochronie informacji niejawnych ${ }^{2}$. Na potrzeby niniejszego opracowania będą to pojęcia synonimiczne.

W Rosji najważniejszym aktem ustanawiającym obywatelskie prawo do informacji oraz określającym sposób jego ograniczania jest Konstytucja FR z 1993 r. ${ }^{3}$ Prawo do poszukiwania, uzyskiwania, przekazywania, wytwarzania, rozpowszechniania i dostępu do informacji zostało określone $\mathrm{w}$ rozdziale drugim tego aktu prawnego pt. Prawa $i$ wolności człowieka i obywatela, w art. 29 ust. $4^{4}$. W drugim zdaniu wymienionego przepisu zaznaczono, że informacje stanowiące tajemnicę państwową wskazuje prawo federalne. Aktualnie jest to ustawa o tajemnicy państwowej z 21 lipca 1993 r. ${ }^{5}$, której postanowienia zostały sprecyzowane w wykazie informacji stanowiących tajemnicę państwową, wprowadzonym dekretem Prezydenta FR z 30 listopada 1995 r. $^{6}$ Zatem ograniczenie prawa do informacji jest możliwe w FR, podobnie

2 Ustawa z dnia 5 sierpnia 2010 r. o ochronie informacji niejawnych (t.j.: DzU z 2019 r. poz. 742).

3 Конституция Российской Федерации от 12 декабря 1993 г., принятая всенародным голосованием 12 декабря 1993 года, вступила в силу в день её официального опубликования в газете „Российская газета” от 25.12.1993 № 237 (Konstytucja Federacji Rosyjskiej z 12 grudnia 1993 r., przyjęta w głosowaniu całego narodu w dniu 12 grudnia 1993 r., obowiązuje od 25 grudnia 1993 r., z dniem jej oficjalnego opublikowania w gazecie „Gazeta Rosyjska" nr 237 - tłum. aut. Wszystkie tłumaczenia w artykule pochodzą od autora przyp. red.); A. Bosiacki, H. Izdebski, Konstytucjonalizm rosyjski. Historia i współczesność, Kraków 2013, s. 271 i nast.

4 Конституция Российской Федерации..., статья 29.4.: „Каждый имеет право свободно искать, получать, передавать, производить и распространять информацию любым законным способом. Перечень сведений, составляющих государственную тайну, определяется федеральным законом” (Konstytucja Federacji Rosyjskiej..., art. 29.4.: „Każdy ma prawo do swobodnego poszukiwania, uzyskiwania, przekazywania, tworzenia i rozpowszechniania informacji w dowolny, zgodny z prawem, sposób. Wykaz informacji stanowiących tajemnicę państwową określa ustawa federalna").

5 Закон Российской Федерации от 21 июля 1993 г., № 5485, „О государственной тайне”, с изменениями, Законодательство Российской Федерации, Сборник основных федеральных законов РФ (Ustawa FR „O tajemnicy państwowej” z 21 lipca 1993 r. nr 5485-1, ze zmianami, Prawodawstwo Federacji Rosyjskiej, Zbiór podstawowych ustaw federalnych), http://fzrf.su/zakon/ogosudarstvennoj-tajne-n-5485-1/ [dostęp: 30 VII 2020].

6 Указ Президента РФ от 30 ноября 1995 г., No 1203, „Об утверждении перечня сведений, отнесенных к государственной тайне" (Dekret Prezydenta FR z 30 listopada 1995 r. nr 1203 
jak w RP, wyłącznie w trybie powszechnie obowiązującej ustawy. Rosyjskim aktem uszczegóławiającym korzystanie z konstytucyjnego prawa do informacji o działalności administracji publicznej jest federalna ustawa o zapewnieniu dostępu do informacji o działalności organów państwowych i samorządów terytorialnych z 9 lutego 2009 r. ${ }^{7}$ W schodni ustawodawca ustanowił w niej prawa wnioskodawcy oraz obowiązki danego organu, a ponadto $\mathrm{w}$ art. 5 określił rodzaje informacji wyłączone $\mathrm{z}$ udostępniania, w tym na rzecz ochrony tajemnicy państwowej ${ }^{8}$. Warto dodać, że procedurę uzyskiwania informacji o działalności sądów FR objęto odrębną regulacją ustawową ${ }^{9}$ Konstytucja FR gwarantuje wolność masowej informacji (mass mediów) i jednocześnie zakazuje cenzury ${ }^{10}$. W polskim porządku prawnym obywatele mają możliwość uzyskiwania (żądania) informacji o działalności organów władzy na podstawie art. 61 ust. 1 Konstytucji RP. Jednocześnie w art. 61 ust. 3 prawodawca stanowi, że to prawo może być ograniczone w trybie ustawy między innymi $\mathrm{z}$ uwagi na bezpieczeństwo państwa ${ }^{11}$. Procedurę korzystania $z$ prawa do informacji określono w ustawie o dostępie do informacji publicznej ${ }^{12}$. Należy zaznaczyć, że w art. 5 ograniczono jej stosowanie między innymi w odniesieniu do informacji niejawnych. Podstawy utajniania informacji dotyczących obszarów wskazanych w Konstytucji, w tym bezpieczeństwa, zostały uszczegółowione w art. 5 ust. 1 i 2 ustawy o ochronie informacji niejawnych.

$\mathrm{Na}$ marginesie tych rozważań trzeba się odnieść do historycznych przemian rosyjskiego ustroju prawnego. Wprowadzenie w 1993 r. nowej Konstytucji FR

„O zatwierdzeniu wykazu informacji stanowiących tajemnice państwową), http://base.garant. $\mathrm{ru} / 10105548 /$ [dostęp: 19 I 2021].

7 Федеральный закон от 9 февраля 2009 г., № 8-Ф3, „Об обеспечении доступа к информации о деятельности государственных органов и органов местного самоуправления" (Ustawa federalna z 9 lutego 2009 r. nr 8-FZ „O zapewnieniu dostępu do informacji o działalności organów państwowych i samorządów terytorialnych”).

8 Tamże, статья 5.1.: „Доступ к информации о деятельности государственных органов и органов местного самоуправления ограничивается в случаях, если указанная информация отнесена в установленном федеральным законом порядке к сведениям, составляющим государственную или иную охраняемую законом тайну” (tamże, art. 5.1.: „Dostęp do informacji o działalności organów państwowych i jednostek samorządu terytorialnego jest ograniczony w przypadkach, gdy te informacje zostaną zaklasyfikowane w sposób określony przez prawo federalne jako informacje stanowiące tajemnicę państwową lub inną tajemnicę ustawowo chronioną").

9 Федеральный закон от 22 декабря 2008 г., № 262-Ф3, „Об обеспечении доступа к информации о деятельности судов в Российской Федерации" (Ustawa federalna z 22 XII 2008 r. nr 262-FZ „O zapewnieniu dostępu do informacji o działalności sądów w Federacji Rosyjskiej”).

10 Конституиия Российской Федерации..., статья 29.5.: „Гарантируется свобода массовой информации. Цензура запрещается” (Konstytucja Federacji Rosyjskiej..., art. 29.5.: „Gwarantuje się wolność środków masowego przekazu. Cenzura jest zabroniona").

11 Konstytucja Rzeczypospolitej Polskiej..., art. 61 ust. 3: „Ograniczenie prawa, o którym mowa w ust. 1 i 2, może nastąpić wyłącznie ze względu na określoną w ustawach ochronę wolności i praw innych osób i podmiotów gospodarczych oraz ochronę porządku publicznego, bezpieczeństwa lub ważnego interesu gospodarczego państwa”.

12 Ustawa z dnia 6 września 2001 r. o dostępie do informacji publicznej (t.j.: DzU z 2020 r. poz. 2176). 
nie spowodowało natychmiastowych zmian w praktyce orzeczniczej sądów oraz normowania ochrony tajemnicy państwowej przez władzę wykonawczą. Podstawowym orzeczeniem Sądu Konstytucyjnego FR w sprawie ponoszenia odpowiedzialności karnej za ujawnienie tajemnicy państwowej jest uchwała z 20 grudnia 1995 r. ze skargi obywatela Władimira Smirnowa. Sąd w uzasadnieniu jednoznacznie wskazał, że ponoszenie odpowiedzialności karnej w związku z ujawnieniem tajemnicy państwowej jest możliwe jedynie wówczas, gdy wykaz informacji stanowiących tajemnicę państwową, o którym mówił art. 29 ust. 4 Konstytucji FR, jest opublikowany w oficjalnej, jawnej i ogólnie dostępnej ustawie federalnej. Sąd wskazał, że wyrok nie może być oparty na nieopublikowanym akcie normatywnym, co wynika $z$ art. 15 ust. 3 Konstytucji $\mathrm{FR}^{13}$. Ten wyrok wpłynął na zmianę dotychczasowej praktyki rosyjskich władz, która polegała na sporządzaniu wykazów informacji stanowiących tajemnicę państwową w aktach niepodlegających publikacji. Przed 1995 r. obywatele FR nie mieli zatem wiedzy o rodzajach informacji objętych ochroną państwa, co utrudniało udowodnienie sprawstwa ujawnienia tajemnicy w kontekście przepisów karnych. Pierwszym aktem opublikowanym, w którym został zawarty wykaz informacji stanowiących tajemnicę państwową, był dekret Prezydenta FR z 30 listopada 1995 r. ${ }^{14}$ (w Polsce pierwszym opublikowanym aktem prawnym precyzującym, jakie informacje stanowią tajemnicę państwową, była ustawa z 1982 r. ${ }^{15}$ ). Profesor Aleksandr Borisow (były sędzia Sądu Konstytucyjnego FR i czołowy przedstawiciel rosyjskiej jurysprudencji) zauważa, że prawo do uzyskiwania i rozpowszechniania informacji $\mathrm{z}$ uwagi na zachowanie ładu społecznego jest ograniczane nawet w dojrzałych demokracjach ${ }^{16}$. Przywołany autor

13 Постановление Конституиионного Суда РФ от 20 декабря 1995 г., № 17-П, по делуо проверке конституционности ряда положений пункта „а" статьи 64 Уголовного кодекса РСФСР в связи с жалобой гражданина B.A. Смирнова (Uchwała Sąu Konstytucyjnego Federacji Rosyjskiej z 20 grudnia 1995 r. nr 17-P w sprawie konstytucyjnej kontroli zakresu przepisu ustępu „a” artykutu 64 Kodeksu karnego FR w zwiazzu ze skarga obywatela W.A. Smirnowa), http://legalacts.ru/doc/ postanovlenie-konstitutsionnogo-suda-rf-ot-20121995-n/ [dostęp: 30 VII 2020]; Конституиця Российской Федерации..., статья 15.3.: „Законы подлежат официальному опубликованию. Неопубликованные законы не применяются. Любые нормативные правовые акты, затрагивающие права, свободы и обязанности человека и гражданина, не могут применяться, если они не опубликованы официально для всеобщего сведения" (Konstytucja Federacji Rosyjskiej..., art. 15.3: „Ustawy podlegają oficjalnej publikacji. Ustawy nieopublikowane nie są stosowane. Wszelkie normatywne akty prawne dotyczące praw, wolności i obowiązków człowieka i obywatela nie są stosowane, jeżeli nie zostały oficjalnie podane do publicznej wiadomości”).

14 Указ Президента РФ от 30 ноября 1995 г., № 1203, „Об утверждении перечня сведений... (Dekret Prezydenta FR z 30 listopada 1995 r. nr 1203 „O zatwierdzeniu wykazu informacji...)

15 Ustawa $z$ dnia 14 grudnia 1982 r. o ochronie tajemnicy państwowej i służbowej (DzU z 1982 r. $\mathrm{nr} 40$ poz. 271, ze zm.). Ustawodawca w art. 6 zobligował administrację rządową do sporządzenia szczegółowych wykazów informacji objętych ochroną w zależności od charakteru danej instytucji i ogłoszenia ich w dziennikach urzędowych, z wyjątkiem informacji dotyczących obronności, Sił Zbrojnych i bezpieczeństwa państwa.

16 А.Б. Борисов, Комментарий $\kappa$ конституиии Российской Федерации (постатейный): с комментариями Конституичионого суда РФ, Москва 2013, s. 56 (A.B. Borisow, Komentarz do Konstytucji Federacji Rosyjskiej..., Moskwa 2013). 
podsumowuje, że rozpowszechnianie tajemnicy państwowej i innych tajemnic chronionych prawem w celu zachęcania do popełniania przestępstw oraz wzniecania konfliktów nacjonalistycznych, rasowych i religijnych jest zakazane w większości krajów. Jednocześnie podkreśla, że zgodnie z obowiązującym prawem wykaz tajemnic państwowych ograniczających wolność słowa może być rozszerzany w czasie wprowadzania stanów nadzwyczajnych lub stanu wojennego ${ }^{17}$. Podobne konsekwencje w odniesieniu do ograniczenia praw i swobód obywatelskich w Polsce są przewidziane $\mathrm{w}$ przypadku wprowadzenia stanu wyjątkowego i wojennego ${ }^{18}$.

W Rosji istnieją trzy tryby sądowego dochodzenia przez stronę naruszonych praw dotyczących dostępu do informacji: przed sądem cywilnym, administracyjnym lub karnym ${ }^{19}$.

Prawo osoby poszkodowanej bezprawną odmową dostępu do informacji albo umyślnym udzieleniem nieprawdziwych informacji do wystąpienia $\mathrm{z}$ powództwem cywilnym do sądu i żądania zadośćuczynienia za szkody powstałe z tego tytułu ustanawia art. 23 ust. 2 ustawy o zapewnieniu dostępu do informacji o działalności organów państwowych i jednostek samorządu terytorialnego ${ }^{20}$. Zasady odpowiedzialności urzędników za naruszenie prawa do informacji zostały określone w art. 25 tej ustawy. Urzędnik winny takiego naruszenia może odpowiadać dyscyplinarnie, administracyjnie ${ }^{21}$, cywilnie lub karnie ${ }^{22}$. Należy dodać, że wnoszący o udzielenie

17 Tamże, s. 57.

18 Zob. szerzej: np. Ustawa $z$ dnia 29 sierpnia 2002 r. o stanie wojennym oraz o kompetencjach Naczelnego Dowódcy Sit Zbrojnych i zasadach podległości konstytucyjnym organom Rzeczypospolitej Polskiej (t.j.: DzU z 2017 r. poz. 1932), art. 13 i art. 24 ust. 1 pkt 7.

19 Юридический энциклопедический словарь, А.В. Малько (red.), Москва 2017, s. 397 (Prawniczy słownik encyklopedyczny, A.W. Malko (red.), Moskwa 2017).

20 Федеральный закон от 9 февраля 2009 г., № 8-ФЗ, „Об обеспечении доступа к информации о деятельности государственных органов..., статья 23.2. „Если в результате неправомерного отказа в доступе к информации о деятельности государственных органов и органов местного самоуправления, либо несвоевременного ее предоставления, либо предоставления заведомо недостоверной или не соответствующей содержанию запроса информации пользователю информацией были причинены убытки, такие убытки подлежат возмещению в соответствии с гражданским законодательством Российской Федерации." (Ustawa federalna $z$ lutego 2009 r. nr 8-FZ „O zapewnieniu dostępu do informacji o działalności organów państwowych...”, art. 23.2. „Jeżeli w wyniku bezprawnej odmowy dostępu do informacji o działalności organów państwowych i jednostek samorządu terytorialnego, ich nieterminowego podania lub podania umyślnie nieprawdziwych informacji lub informacji niezgodnych z treścią żądania, wyrządzono wnioskodawcy szkody, szkody te podlegają naprawieniu zgodnie z prawem cywilnym Federacji Rosyjskiej").

21 Odpowiedzialność administracyjna urzędnika jest egzekwowana na podstawie przepisów federalnego kodeksu o wykroczeniach administracyjnych. Zob. Федеральный закон от 30 декабря 2001 г., No 195-ФЗ, „Кодекс Российской Федерации об административных правонарушениях” (Ustawa federalna z 30 grudnia 2001 r. nr 195-FZ „Kodeks Federacji Rosyjskiej o wykroczeniach administracyjnych").

22 Федеральный закон от 9 февраля 2009 г., $N^{\circ}$ 8-ФЗ, „Об обеспечении доступа $\kappa$ информации о деятельности государственных органов..., статья 25.: „Должностные 
informacji w toku postępowania administracyjnego (również przed uzyskaniem rozstrzygnięcia) może złożyć skargę na czynności organu do Prokuratury Federalnej FR, która na podstawie art. 24 ust. 3 ustawy przywołanej na wstępie sprawuje urzędowy nadzór nad jej stosowaniem ${ }^{23}$. Szczegółowe uprawnienia prokuratury w odniesieniu do ochrony praw i wolności człowieka i obywatela, a więc również konstytucyjnego prawa do informacji, określono w artykułach 26-29 ustawy o prokuraturze FR $^{24}$. W przypadku uzasadnionej skargi prokurator jest zobowiązany do ścigania urzędników, którzy złamali prawo, a na etapie sporu przed sądem administracyjnym może włączyć się do postępowania po stronie żądającego informacji, o czym stanowi art. 218 ust. 4 i art. 39 ust. 7 ustawy Kodeks postępowania przed sądami administracyjnymi Federacji Rosyjskiej ${ }^{25}$.

Egzekwowanie prawa do informacji na szczeblu kolejnych instancji organów państwowych i samorządowych oraz przed sądem administracyjnym jest realizowane na podstawie art. 23 ust. $1^{26} \mathrm{w}$ związku $\mathrm{z}$ art. 8 ust. 4 tej ustawy. Wnoszenie odwołania od odmowy udzielenia informacji do organów drugiego stopnia odbywa się zgodnie

лица государственных органов и органов местного самоуправления, государственные и муниципальные служащие, виновные в нарушении права на доступ к информации о деятельности государственных органов и органов местного самоуправления, несут дисциплинарную, административную, гражданскую и уголовную ответственность в соответствии с законодательством Российской Федерации" (Ustawa federalna z 9 lutego 2009 r. nr 8-FZ „O zapewnieniu dostępu do informacji o działalności organów państwowych...”, art. 25: „Urzędnicy organów państwowych i samorządowych, pracownicy państwowi i samorządowi winni naruszenia prawa dostępu do informacji o działalności organów państwowych i samorządowych ponoszą odpowiedzialność dyscyplinarną, administracyjną, cywilną i karną zgodnie z ustawodawstwem Federacji Rosyjskiej").

23 Tamże, статья 24.3.: „Надзор за исполнением государственными органами, органами местного самоуправления, их должностными лицами настоящего Федерального закона осуществляют органы прокуратуры Российской Федерации в порядке, установленном Федеральным законом” "О прокуратуре Российской Федерации»” (tamże, art. 24.3.: „Nadzór nad wykonywaniem niniejszej Ustawy Federalnej przez organy państwowe, organy samorządu lokalnego i ich funkcjonariuszy sprawują organy Prokuratury Federacji Rosyjskiej w sposób określony w ustawie federalnej «O prokuraturze Federacji Rosyjskiej»").

24 Федеральный закон от 17 января 1992 г., № 2202-1, „О прокуратуре Российской Федераиии” (Ustawa federalna z 17 stycznia 1992 r. nr 2202-1 „O prokuraturze Federacji Rosyjskiej”).

25 Федеральный закон от 8 марта 2015, $N^{\circ}$ 21-Ф3, „Кодекс административного судопроизводства Российской Федерации” (Ustawa federalna $z 8$ marca 2015 r. $\mathrm{nr}$ 21-FZ „Kodeks postępowania przed sądami administracyjnymi Federacji Rosyjskiej”).

26 Федеральный закон от 9 февраля 2009 г., № 8-ФЗ..., статья 23.1. „Решения и действия (бездействие) государственных органов и органов местного самоуправления, их должностных лиц, нарушающие право на доступ к информации о деятельности государственных органов и органов местного самоуправления, могут быть обжалованы в вышестоящий орган или вышестоящему должностному лицу либо в суд" (Ustawa federalna z 9 lutego 2009 r. nr 8-FZ..., art. 23.1.: „Decyzje i działania (bezczynność) organów państwowych i samorządowych, ich urzędników, naruszające prawo dostępu do informacji o działalności organów państwowych i samorządu terytorialnego, mogą być zaskarżane do organów nadrzędnych lub wyższego urzędnika albo do sądu”). 
z ogólną procedurą określoną w ustawie federalnej o wnoszeniu odwołań ${ }^{27}$, skargę do sądu administracyjnego wnosi się natomiast zgodnie z postanowieniami kodeksu postępowania przed sądami administracyjnymi ${ }^{28}$.

Z powyższych rozważań wynika, że rosyjskie i polskie regulacje konstytucyjne w głównych postanowieniach są zbieżne: ustanawiają obywatelskie prawo do uzyskiwania informacji oraz do ich rozpowszechniania i jednocześnie wprowadzają przesłanki, które ograniczają obowiązek organów państwa w zakresie udzielania informacji obywatelom. Uszczegółowieniem norm konstytucyjnych są powszechnie obowiązujące ustawy, w których prawodawca sprecyzował sposób egzekwowania prawa do informacji oraz kategorie informacji niepodlegające udostępnieniu.

\section{Karnoprawna ochrona tajemnicy państwowej w Federacji Rosyjskiej. Wybrane odniesienia do prawa polskiego}

W celu wymuszenia przestrzegania przepisów o ochronie tajemnicy państwowej (informacji niejawnych) w RP ustanowiono odpowiednie instytucje prawa karnego, które wprowadzają sankcje karne za naruszenie bezpieczeństwa tajemnic. Rosyjskie prawodawstwo karne zalicza przestępstwa dotyczące tajemnicy państwowej do kategorii przestępstw skierowanych przeciwko bezpieczeństwu państwa. Polskie ustawodawstwo odeszło od tego rodzaju systematyki po wprowadzeniu kodeksu karnego z 1969 r., w którym przestępstwo przeciwko tajemnicy państwowej przyporządkowano do rozdziału XXXIV pt.: Przestępstwa naruszenia tajemnicy państwowej i służbowej. Należy wskazać, że aktualny kodeks karny RP z 1997 r. ${ }^{29}$ zalicza przepisy karne sankcjonujące ujawnienie lub wykorzystanie informacji niejawnych do rozdziału XXXIII pt. Przestępstwa przeciwko ochronie informacji ${ }^{30}$. Kodeks karny FR (ros. уголовньий

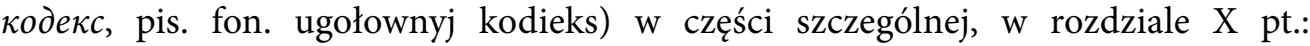

27 Федеральньй закон от 2 мая 2006 г., $N^{\circ}$ 59-Ф3, „О порядке рассмотрения обращений граждан Российской Федерации” (Ustawa federalna z 2 maja 2006 nr 59-FZ „O procedurze rozpatrywania odwołań obywateli Federacji Rosyjskiej).

28 Федеральный закон „Кодекс административного судопроизводства...

29 Ustawa z dnia 6 czerwca 1997 r. - Kodeks karny (t.j.: DzU z 2020 r. poz. 1444, ze zm.).

30 W związku z włączeniem przepisów karnych dotyczących przestępczego ujawnienia lub wykorzystania informacji niejawnych do rozdziału XXXIII pt. Przestępstwa przeciwko ochronie informacji powstało wiele opinii odnoszących się do normotwórczego charakteru tego tytułu i jego wpływu na wykładnię przepisów w nim zgrupowanych. Zob. szerzej: W. Wróbel, Prawnokarna ochrona tajemnicy państwowej, „Czasopismo Prawa Karnego i Nauk Penalnych” 2000, nr 1, s. 124 i nast.; M. Leciak, Karnoprawna ochrona informacji niejawnych, Toruń 2012, s. 125; W. Wróbel, Pojęcie „dobra prawnego” w wykładni przepisów prawa karnego, w: Aktualne problemy prawa karnego. Księga pamiątkowa z okazji jubileuszu 70. urodzin profesora Andrzeja J. Szwarca, Ł. Pohl (red.), Poznań 2009, s. 628-629; Uchwała Sądu Najwyższego z 26 IX 2002 r., I KZP 25/02, wskazująca między innymi na niekonsekwencję prawodawcy w grupowaniu przepisów karnych w rozdziały według kryterium dobra chronionego. 
Przestęstwa przeciwko władzy państwowej, w podrozdziale 29 zatytułowanym Przestępstwa przeciwko podstawom porzadku konstytucyjnego i bezpieczeństwa państwa, zawiera trzy jednostki redakcyjne: art. 283 , art. $283^{1}$ (z cyfrą „1”) oraz art. $284^{31}$. Należy podkreślić, że kodeks $\mathrm{w}$ uchwalonej wersji nie zawierał art. $283^{1}$, który został dodany nowelą numer 190-FZ z 12 listopada 2012 r.

Rozpowszechnianie tajemnicy państwowej jest spenalizowane w art. 283 kk FR ${ }^{32}$. Podmiot przestępstwa został tu określony jako indywidualny. Jest nim osoba, której powierzono określone tajemnice, lub osoba, która zapoznała się z tymi tajemnicami w związku z pełnieniem obowiązków służbowych, pracą albo nauką, a także w innych okolicznościach prawnie określonych przepisami Federacji Rosyjskiej. W rosyjskiej literaturze przedmiotu zwraca się uwagę na to, że nie tylko osoby mające legalny dostęp do tajemnicy państwowej stanowią potencjalny podmiot przestępstwa polegającego na jej ujawnieniu. Autorzy wskazują, że niektórzy pracownicy mogą mieć pośrednią styczność $\mathrm{z}$ tajemnicą w ramach wykonywanych obowiązków (np. pracownicy ochrony, kurierzy, kierowcy oraz personel pomocniczy w instytucjach przetwarzających tajemnice $)^{33}$.

Przedmiotem ochrony są informacje stanowiące tajemnicę państwową. Zarówno rosyjski kodeks karny, jak i polski - z 1997 r. (art. 265 i art. 266), nie zawierają definicji informacji, o których stanowią. Rosyjskie pojęcie „tajemnica państwowa” zostało określone w odrębnej ustawie, o czym będzie mowa w części artykułu dotyczącej rosyjskiego prawa administracyjnego, normującego zarządzanie tajemnicami. Przepisy karnego

31 Уголовный кодекс Российской Федерации от 13 июня 1996 г., № 63-Ф3, с изменениями, Законодательство Российской Федерации, Сборник основных федеральных законов РФ (Kodeks karny Federacji Rosyjskiej z 13 czerwca 1996 r. nr 63-FZ, ze zmianami, Prawodawstwo Federacji Rosyjskiej, Zbiór podstawowych ustaw federalnych FR); https://fzrf.su/kodeks/uk/ [dostęp: 9 II 2021].

32 Tamże, статья 283.1.: „Разглашение сведений, составляющих государственную тайну, лицом, которому она была доверена или стала известна по службе, работе, учебе или в иных случаях, предусмотренных законодательством Российской Федерации, если эти сведения стали достоянием других лиц, при отсутствии признаков преступлений, предусмотренных статьями 275 и 276 настоящего Кодекса - наказывается арестом на срок от четырех до шести месяцев либо лишением свободы на срок до четырех лет с лишением права занимать определенные должности или заниматься определенной деятельностью на срок до трех лет или без такового” (tamże, art. 283.1.: „Rozpowszechnianie informacji stanowiących tajemnicę państwową przez osobę, której je powierzono lub stały się jej znane $\mathrm{w}$ związku z pełnieniem obowiązków służbowych, pracą, nauką lub $\mathrm{w}$ innych przypadkach, przewidzianych ustawodawstwem Federacji Rosyjskiej, jeżeli te informacje stały się znane innym osobom, przy braku znamion przestępstw przewidzianych w artykułach 275 i 276 niniejszego kodeksu - skazuje się (zagrożone jest) karą aresztu na okres od czterech do sześciu miesięcy albo na karę pozbawienia wolności na okres do czterech lat $\mathrm{z}$ pozbawieniem prawa do zajmowania określonych stanowisk lub zajmowania się określoną działalnością na okres do trzech lat, lub bez tego" (tj. bez zastosowania dodatkowych środków karnych).

33 Zob. szerzej: В.М. Лебедев, Уголовный кодекс Российской Федераиии с научно-практическим комментарием, Варшава 1997, s. 543 i nast. (W.M. Lebiediew, Kodeks karny Federacji Rosyjskiej z naukowo-praktycznymi komentarzami, Warszawa 1997, s. 543 i nast.). 
prawa materialnego w Rosji, podobnie jak i w Polsce, są w tej części blankietowe ${ }^{34}$. To oznacza konieczność poszukiwania adekwatnych definicji terminów użytych do ich konstrukcji w innych powszechnie obowiązujących aktach prawnych.

W rosyjskim prawodawstwie strona przedmiotowa (czynność sprawcza) polega na „rozpowszechnianiu” tajemnicy państwowej, czyli czasownikowej formie dokonanej. Przestępstwo jest znamienne skutkiem (jest przestępstwem materialnym) w postaci intelektualnego zapoznania się z ujawnionymi treściami przez inną osobę. Istota rozpowszechnienia, $\mathrm{w}$ polskim prawodawstwie określana jako ujawnienie, zawiera się $\mathrm{w}$ udostępnieniu danej tajemnicy innej osobie. W rosyjskim piśmiennictwie zwraca się uwagę na sposób rozpowszechniania, przyjmując, że każda bezprawna forma zastosowana przez sprawcę, która skutkuje ujawnieniem tajemnicy wobec innej osoby, wypełnia to znamię. Ponadto osoba nieuprawniona jest charakteryzowana jako osoba nieposiadająca legalnego dostępu do tajemnicy państwowej, a także jako osoba, która ma dostęp do tajemnicy państwowej, ale zapoznaje się z informacją niepowiązaną $\mathrm{z}$ zajmowanym stanowiskiem czy pełnioną funkcją ${ }^{35}$. Rosyjski ustawodawca w treści przepisu wprowadza zastrzeżenie, że za rozpowszechnianie tajemnicy sprawca ponosi odpowiedzialność przewidzianą $\mathrm{w}$ tym przepisie, o ile swoim czynem nie wypełnił znamion przestępstwa szpiegostwa albo zdrady stanu. Wymienione przestępstwa różnią się od rozpowszechniania tajemnicy zamiarem, znamiona zdrady lub szpiegostwa bowiem zostają spełnione jedynie wówczas, gdy sprawca jest świadomy, że przekazuje tajemnice obcemu państwu, organizacji międzynarodowej albo obcej organizacji lub ich przedstawicielstwom $\mathrm{w}$ celu wykorzystania tych tajemnic przeciwko bezpieczeństwu FR.

Omawiane przestępstwo można popełnić tylko umyślnie, w zamiarze bezpośrednim (ros. непосредственный - bezpośredni) lub pośrednim (ros. косвенный pośredni), który w polskim piśmiennictwie jest nazywany „ewentualnym”. Rosyjska doktryna prawa karnego przewiduje możliwość sprawstwa również przez zaniechanie - jako przykład podaje się urzędnika, który pozostawia niezabezpieczone tajne

${ }^{34}$ Igor Andrejew definiuje, że przepisy blankietowe to przepisy, które nie zawierają pełnego opisu czynu zabronionego. Dodatkowo zauważa, że ustawodawca w ich treści nie odsyła do innego przepisu kodeksu lub innego konkretnego aktu, lecz „(...) powołuje się tylko na nieokreślone ustawy, rozporządzenia lub inne akty normatywne, na których podstawie należy ustalić, na czym polega dany czyn zabroniony" (I. Andrejew, Polskie prawo karne w zarysie, Warszawa 1989, s. 76). Uwagi o problemach w rekonstrukcji normy karnej, wynikających z przepisów blankietowych, czyni również Ryszard Dębski. Jako przykład ekstremalny przywołuje konieczność zastosowania w toku tego procesu reguł nieprawnokarnych, które są formułowane nieco inaczej niż opisy czynów zabronionych. Wskazuje, że trudności w recepcji tych przepisów wynikają przede wszystkim z ich nieprecyzyjnej konstrukcji - braku jednoznaczności, która jest wymagana w prawie karnym. Autor dostrzega dodatkowe problemy interpretacyjne wynikające z zastosowania przez ustawodawcę „blankietu ogólnego”, który należy wypełnić, tj. odszukać i zastosować znamiona ustanowione w wielu innych aktach. Podsumowuje, że czyni to przepis karny mało czytelnym i może naruszać funkcję gwarancyjną, która polega na „przewidywalności” reakcji karnej na zachowanie opisane prawem karnym (R. Dębski, Pozaustawowe znamiona przestępstwa, Łódź 1995, s. 118).

35 В.М. Лебедев, Уголовный кодекс Российской Федерации..., s. 542. 
dokumenty ${ }^{36}$. Istotną różnicą między art. $283 \mathrm{kk}$ FR i art. $265 \S 1 \mathrm{kk} \mathrm{RP}$ jest podmiotowy zakres zakazu karnego: w regulacji rosyjskiej podmiotem przestępstwa mogą być osoby mające szczególne uprawnienia (podmiot indywidualny), a w polskiej - każdy (podmiot powszechny). Polski przepis penalizuje ponadto nie tylko ujawnienie, lecz także nieuprawnione wykorzystanie tajemnic.

Rodzajów kar przyjętych przez rosyjskiego prawodawcę jest więcej niż przyjętych przez polskiego prawodawcę. Czyn polegający na rozpowszechnianiu tajemnicy państwowej w typie podstawowym jest zagrożony karą aresztu na okres od czterech do sześciu miesięcy albo karę pozbawienia wolności do czterech lat, z możliwością orzeczenia pozbawienia prawa do zajmowania określonych stanowisk albo zajmowania się określoną działalnością na okres do trzech lat. Warto zauważyć, że zastosowanie przez sąd RP środków karnych we wskazanej postaci na podstawie art. 41 kk RP nie jest wykluczone, orzeczenie kary aresztu jest jednak niemożliwe.

W rosyjskim prawie karnym zaostrzenie odpowiedzialności za bezprawne rozpowszechnianie tajemnic następuje wówczas, gdy czyn zaistniał z powodu nieostrożności i wywołał ciężkie następstwa ${ }^{37}$. Polskim odpowiednikiem tej formy winy jest nieumyślność (art. 9 ust. 2 kk z 1997 r. ${ }^{38}$ ). W Federacji Rosyjskiej rozróżnia się rodzaje nieostrożności w postaci lekkomyślności albo niedbalstwa (art. 26 ust. 1 kk FR), podobnie jak rozróżniał to polski kodeks karny z 1969 r. W przypadku wywołania ciężkich następstw spowodowanych powyższymi zaniedbaniami ustawodawca zwiększa okres kary izolacyjnej przez podwyższenie jej dolnego i górnego wymiaru, odpowiednio od trzech do siedmiu lat. Przepis wprowadza dodatkowo obowiązkowe orzeczenie zakazu zajmowania określonych stanowisk lub prowadzenia określonej działalności na okres do trzech lat. Zwiększone sankcjonowanie nieostrożności powodującej ciężkie następstwa czynu może zaskakiwać. Należy jednak uwzględnić, że kodeks karny FR w art. $27^{39}$ przewiduje

36 А.Б. Борисов, Комментарий к уголовному кодексу..., s. 681 i nast. (A.B. Borisow, Komentarz do kodeksu karnego..., s. 681 i nast.).

37 Уголовный кодекс Российской Федерации от 13 июня 1996 г., № 63-ФЗ, с изменениями..., статья 283.2.: „То же деяние, повлекшее по неосторожности тяжкие последствия наказывается лишением свободы на срок от трех до семи лет с лишением права занимать определенные должности или заниматься определенной деятельностью на срок до трех лет” (Kodeks karny Federacji Rosyjskiej..., art. 283.2.: „Za ten czyn, który z powodu nieostrożności spowodował ciężkie następstwa - skazuje się na karę pozbawienia wolności na okres od trzech do siedmiu lat z pozbawieniem prawa do zajmowania określonych stanowisk lub zajmowania się określoną działalnością na okres do trzech lat").

38 Ustawa $z$ dnia 6 czerwca 1997 r. - Kodeks karny...

39 Уголовный кодекс Российской Федераиии от 13 июня 1996 г., № 63-ФЗ, с изменениями..., статья 27.: „Если в результате совершения умышленного преступления причиняются тяжкие последствия, которые по закону влекут более строгое наказание и которые не охватывались умыслом лица, уголовная ответственность за такие последствия наступает только в случае, если лицо предвидело возможность их наступления, но без достаточных к тому оснований самонадеянно рассчитывало на их предотвращение, или в случае, если лицо не предвидело, но должно было и могло предвидеть возможность наступления этих последствий. В целом такое преступление признается совершенным умышленно" (Kodeks karny Federacji 
odpowiedzialność za popełnienie czynu z podwójnym zawinieniem, tj. winą umyślną i nieumyślną (ros. неосторожность - nieostrożność). Zaostrzona odpowiedzialność jest spowodowana kwalifikowaniem czynu ze względu na jego następstwa. Jest to forma winy mieszanej, stanowiąca odpowiednik opisany w art. $9 \S 3$ polskiego kodeksu karnego $\mathrm{z} 1997 \mathrm{r}$. Zgodnie $\mathrm{z}$ art. 15 ust. 3 i 4 kk FR przestępstwo $\mathrm{z}$ art. 283 ust. 1 jest zaliczane do średnio ciężkich, a z ust. 2 do ciężkich, co ma wpływ na sądowy wymiar kary. Sąd może wziąć pod uwagę faktyczne okoliczności czynu i spowodowany przez niego stopień publicznego niebezpieczeństwa (czego odpowiednikiem w RP jest społeczna szkodliwość czynu) i orzec wymiar kary przewidziany dla przestępstw tylko o jeden stopień lżejszych. Na marginesie należy zauważyć, że w stosunku do art. 283, art. $283^{1}$ i 284 organem właściwym do prowadzenia postępowania przygotowawczego jest Federalna Służba Bezpieczeństwa (dalej: FSB ${ }^{40}$.

Kolejnym przestępstwem zagrażającym bezpieczeństwu FR jest bezprawne uzyskanie informacji stanowiących tajemnicę państwową (art. $283^{1} \mathrm{kk} \mathrm{FR}^{41}$ ). Karnoprawnym zakazem został objęty czyn umyślny polegający na nielegalnym wejściu w posiadanie tajemnicy państwowej w wyniku: kradzieży, oszustwa, szantażu, zmuszenia, groźby użycia przemocy lub w inny bezprawny sposób. Normodawca określił podmiot przestępstwa jako powszechny - przepis nie stanowi o osobowym ograniczeniu sprawstwa. Przedmiot ochrony jest tożsamy z przyjętym w art. 283.

Strona przedmiotowa czynu zabronionego jest rozbudowana, sprawca zmierzający do uzyskania informacji nie wypełnia znamion, jeśli stosuje środki prawnie dopuszczalne. Jeżeli osiągnięcie celu następuje w wyniku zastosowania sposobów zabronionych, chociażby jednego z wyżej wymienionych, wówczas zostaje naruszona norma

Rosyjskiej..., art. 27.: „Jeżeli wskutek popełnienia przestępstwa umyślnego dojdzie do poważnych następstw, które zgodnie z prawem pociągają za sobą surowszą karę i które nie były objęte zamiarem osoby, odpowiedzialność karna za takie następstwa powstaje tylko w przypadku, gdy dana osoba przewidywała możliwość ich wystąpienia, ale bez dostatecznych podstaw lekkomyślnie sądziła, że im zapobiegnie albo w przypadku, gdy dana osoba nie przewidywała, ale powinna i mogła przewidzieć możliwość wystąpienia takich następstw. Takie przestępstwo uznaje się za popełnione umyślnie").

40 О.О. Скоробогатова, С.А. Перчаткина, Уголовный кодекс Российской Федераиии с комментариями, Москва 2012, s. 234 (O.O. Skorobogatowa, S.A. Pierczatkina, Kodeks karny Federacji Rosyjskiej z komentarzami, Moskwa 2012).

${ }_{41}$ Уголовньй кодекс Российской Федераиии от 13 июня 1996 г., № 63-ФЗ, с изменениями...,

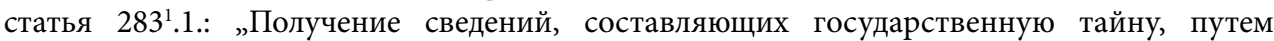
похищения, обмана, шантажа, принуждения, угрозы применения насилия либо иным незаконным способом (при отсутствии признаков преступлений, предусмотренных статьями 275 и 276 настоящего Кодекса) - наказывается штрафом в размере от двухсот тысяч до пятисот тысяч рублей или в размере заработной платы или иного дохода осужденного за период от одного года до трех лет либо лишением свободы на срок до четырех лет" (Кodeks karny Federacji Rosyjskiej..., art. 283'.1.: „Za uzyskanie informacji stanowiących tajemnicę państwową drogą kradzieży, oszustwa, szantażu, zmuszenia, groźby użycia przemocy lub innym bezprawnym sposobem (przy braku znamion przestępstw przewidzianych w artykułach 275 i 276 niniejszego kodeksu) - skazuje się na karę grzywny w wysokości od dwustu tysięcy do pięciuset tysięcy rubli lub w wysokości wynagrodzenia za pracę, lub innego dochodu skazanego, za okres od jednego roku do trzech lat albo na karę pozbawienia wolności na okres do czterech lat"). 
zakazu karnego. Jak trafnie zauważa Jurij Pudowoczkin, przy ocenie bezprawności uzyskania tajemnicy państwowej należy opierać się na przepisach materialnych prawa karnego oraz regulacjach ustawy z 21 lipca 1993 r. o tajemnicy państwowej ${ }^{42}$. Rosyjski prawodawca warunkuje odpowiedzialność karną $\mathrm{z}$ art. $283^{1} \mathrm{kk}$ FR brakiem wypełnienia znamion przestępstw z art. 275 (zdrada) i art. $272 \mathrm{kk}$ FR (szpiegostwo). Zagrożenie karą jest przemienne, sąd może orzec karę pozbawienia wolności na okres do czterech lat albo grzywnę w wysokości od 200 tys. do 500 tys. rubli, z możliwością oznaczenia jej wysokości krotnością wynagrodzenia za pracę lub innego dochodu za okres od jednego roku do trzech lat.

W ustępie drugim omawianego przepisu sklasyfikowano przestępstwo według sposobu jego popełnienia lub jego określonego skutku ${ }^{43}$. Ustawodawca podwyższa górną granicę odpowiedzialności karnej z czterech do ośmiu lat pozbawienia wolności, jeżeli czyn został popełniony: przez grupę osób, z użyciem przemocy, z wykorzystaniem specjalnych środków technicznych i innych środków przeznaczonych do niejawnego uzyskiwania informacji, spowodował ciężkie następstwa, był związany z rozpowszechnianiem tajemnicy państwowej albo z przekazaniem nośników tajemnicy państwowej poza granice FR. Zagrożenie karą zmienia stopień przestępstwa ze średniego na ciężkie.

Na uwagę zasługuje generalna norma zakazu ustanowiona art. $283^{1}$ ust. 1, sankcjonowaniu karnemu podlega bowiem uzyskanie informacji stanowiących tajemnicę państwową, nawet bez ich wykorzystania lub ujawnienia. Podstawowym skutkiem jest więc uzyskanie niejawnych informacji, typ kwalifikowany tego przestępstwa natomiast jest determinowany jego określonym rezultatem, np. ciężkimi następstwami godzącymi w bezpieczeństwo państwa albo sposobem sprawstwa. Odwołując się do historii, należy stwierdzić, że w przeszłości w polskim prawodawstwie istniały podobne

42 Ю.Е. Пудовочкин, Преступления против государственной власти, в: Комментарий $\kappa$ Уголовному кодексу Российской Федерации, t. 2, А.В. Бриллиантов (red.), Москва 2017, s. 376 (E. Pudowoczkin, Przestępstwa przeciwko władzy państwowej, w: Komentarz do Kodeksu karnego Federacji Rosyjskiej, t. 2, A.W. Briliantow (red.), Moskwa 2017).

43 Уголовный кодекс Российской Федераиии от 13 июня 1996 г., № 63-ФЗ, с изменениями..., статья $283^{1} .2 .:$ „То же деяние, если оно:

a) совершено группой лиц;

б) совершено с применением насилия;

в) повлекло наступление тяжких последствий;

г) совершено с использованием специальных и иных технических средств предназначенных для негласного получения информации;

д) сопряжено с распространением сведений, составляющих государственную тайну, либо с перемещением носителей таких сведений за пределы Российской Федерации наказывается лишением свободы на срок от трех до восьми лет" (Kodeks karny Federacji Rosyjskiej..., art. $283^{1} .2 .:$ „Za ten czyn, jeżeli: a) został on popełniony przez grupę osób, b) został popełniony z użyciem przemocy, w) spowodował ciężkie następstwa, g) został popełniony z wykorzystaniem specjalnych i innych środków technicznych przeznaczonych do niejawnego uzyskania informacji, d) był związany $\mathrm{z}$ rozpowszechnieniem informacji stanowiących tajemnicę państwową lub z przekazaniem nośników takich informacji poza granice Federacji Rosyjskiej skazuje się na karę pozbawienia wolności na okres od trzech do ośmiu lat"). 
przepisy $^{44}$. Penalizacji bezprawnego uzyskiwania (gromadzenia) tajemnicy państwowej zaprzestano wraz z wprowadzeniem kodeksu karnego z 1969 r. Aktualnie tego rodzaju czyn może skutkować odpowiedzialnością z art. 267 § 1 kk, który sankcjonuje nielegalne uzyskanie informacji ${ }^{45}$.

Ostatnim przepisem wprowadzającym karnoprawną ochronę tajemnic Federacji Rosyjskiej jest art. 284 kk FR ${ }^{46}$. Kryminalizuje on utratę dokumentów stanowiących tajemnicę państwową albo przedmiotów chronionych taką tajemnicą w wyniku naruszenia zasad tej ochrony przez legalnego dysponenta. Podmiot przestępstwa został określony indywidualnie - jest nim osoba uprawniona do dostępu do tajemnicy państwowej i będąca w posiadaniu danych tajemnic zgodnie $\mathrm{z}$ uprawnieniami. Borisow wyszczególnia rodzajowy przedmiot ochrony, który określa jako właściwe funkcjonowanie władz państwowych, oraz indywidualny przedmiot ochrony, którym jest bezpieczeństwo państwa ${ }^{47}$.

Strona podmiotowa jest złożona, tj. umyślno-nieumyślna. W odniesieniu do naruszenia przepisów określających zasady ochrony utraconych nośników sprawca działa w zamiarze bezpośrednim lub ewentualnym (przyjmuje się, że osoba mająca legalny dostęp do informacji niejawnych ma odpowiednią wiedzę w zakresie zasad ochrony

${ }^{44}$ Rozporzadzenie Prezydenta Rzeczypospolitej z dnia 16 lutego 1928 r. o karach za szpiegostwo i niektóre inne przestępstwa przeciw Państwu (DzU z 1928 r. nr 18 poz. 160), art. 5; Rozporzadzenie Prezydenta Rzeczypospolitej z dnia 24 października 1934 r. o niektórych przestępstwach przeciwko bezpieczeństwu Państwa (DzU z 1934 r. nr 94 poz. 851), art. 15; Dekret z dnia 16 listopada 1945 r. o przestępstwach szczególnie niebezpiecznych $w$ okresie odbudowy Państwa (DzU z 1945 r. nr 53 poz. 300), art. 8; Dekret $z$ dnia 13 czerwca 1946 r. o przestępstwach szczególnie niebezpiecznych w okresie odbudowy Państwa (DzU z 1946 r. nr 30 poz. 192), art. 7; Dekret z dnia 26 października 1949 r. o ochronie tajemnicy państwowej i stużbowej (DzU z 1949 r. nr 55 poz. 437), art. 3 i 4.

45 B. Kunicka-Michalska, Przestępstwa przeciwko ochronie informacji i wymiarowi sprawiedliwości, Warszawa 2000, s. 428; A. Marek, Prawo karne, Warszawa 2016, s. 688; M. Leciak, Karnoprawna ochrona informacji..., s. 253.

46 Уголовный кодекс Российской Федераиии от 13 июня 1996 г., No 63-ФЗ, с изменениями..., статья 284: „Нарушение лицом, имеющим допуск к государственной тайне, установленных правил обращения с содержащими государственную тайну документами, а равно с предметами, сведения о которых составляют государственную тайну, если это повлекло по неосторожности их утрату и наступление тяжких последствий, - наказывается ограничением свободы на срок до трех лет, либо арестом на срок от четырех до шести месяцев, либо лишением свободы на срок до трех лет с лишением права занимать определенные должности или заниматься определенной деятельностью на срок до трех лет или без такового” (Kodeks karny Federacji Rosyjskiej..., art. 284.: „Za naruszenie ustanowionych zasad obchodzenia się z dokumentami zawierającymi tajemnicę państwową, jak i z przedmiotami, o których informacje stanowią tajemnicę państwową, przez osobę mającą dostęp do tajemnicy państwowej, jeżeli z powodu nieostrożności spowodowało to ich utratę i ciężkie następstwa skazuje się na karę ograniczenia wolności na okres do trzech lat albo na karę aresztu na okres od czterech do sześciu miesięcy, albo na karę pozbawienia wolności na okres do trzech lat z pozbawieniem prawa do zajmowania określonych stanowisk lub prowadzenia określonej działalności na okres do trzech lat lub bez tego" (tj. bez zastosowania środków karnych).

47 Zob. szerzej: А.Б. Борисов, Комментарий к уголовному кодексу..., s. 683 i nast. (A.B. Borisow, Komentarz do kodeksu karnego..., s. 683 i nast.). 
tych informacji i umyślnie od nich odstępuje). Nieumyślność (ros. неосторожность nieostrożność) jest związana z lekkomyślnym przekonaniem, że naruszenie przepisów nie spowoduje utraty nośników informacji i ciężkich następstw. Skutkiem czynu zabronionego jest utrata dokumentów, które są nośnikami tajemnicy państwowej, albo przedmiotów, z którymi taka tajemnica jest związana. Warunkiem odpowiedzialności jest spowodowanie ciężkich następstw godzących w bezpieczeństwo FR. Pojęcie ciężkie następstwa nie jest zdefiniowane w rosyjskim prawodawstwie. Według Borisowa zaliczenie skutków do ciężkich zawsze pozostaje w gestii sądu, który rozważa szczególnie utratę tajemnicy na rzecz obcych wywiadów oraz szkodę materialną w dużych rozmiarach. Dla wypełnienia znamion czynu jest konieczne zaistnienie związku przyczynowo-skutkowego. Utrata informacji stanowiących tajemnicę państwową, zawartych $\mathrm{w}$ dokumentach, albo przedmiotów, $\mathrm{z}$ którymi tajemnica jest związana, musi wynikać z naruszenia konkretnych przepisów dotyczących sposobu ochrony utraconych nośników tajemnicy, które należy traktować jako przedmiot wykonawczy tego przestępstwa.

Rosyjski kodeks karny przewiduje następujące rodzaje kar za przestępstwo utraty tajemnicy państwowej: ograniczenie wolności na okres do trzech lat, areszt na okres od czterech do sześciu miesięcy, pozbawienie wolności na okres do trzech lat $\mathrm{z}$ fakultatywnym orzeczeniem zakazu zajmowania określonych stanowisk lub prowadzenia określonej działalności na okres do trzech lat.

Przepisy wprowadzające odpowiedzialność karną za utratę dokumentu lub innego przedmiotu stanowiącego tajemnicę państwową, a także za naruszenie zarządzeń określających ich ochronę, obowiązywały w Polsce do dnia wprowadzenia kodeksu karnego z 1997 r. Był to art. 262 i art. $263 \mathrm{kk} \mathrm{z} 1969$ r. ${ }^{48} \mathrm{~W}$ aktualnym stanie prawnym utrata niejawnych dokumentów lub materiałów oraz naruszenie zasad ochrony nie są penalizowane w art. $265 \mathrm{kk}$ lub $266 \mathrm{kk}$, o ile nie doprowadziły do ujawnienia albo wykorzystania informacji wskazanych $w$ ich treści ${ }^{49}$. Możliwa jest oczywiście odpowiedzialność karna z powyższych artykułów nawet bez przestępnego dokonania czy$\mathrm{nu}$, przy uwzględnieniu formy stadialnej, tj. usiłowania ${ }^{50}$, oraz niesprawczych postaci zjawiskowych ${ }^{51}$ (podżegania i pomocnictwa). Skomplikowanym stanem faktycznym, powodującym złożoną kwalifikację prawną czynu, mogłoby być zaniechanie obowiązków przez funkcjonariusza, który na mocy art. 2 kk jest gwarantem nienastąpienia skutku. W wyniku niedopełnienia obowiązków funkcjonariusz publiczny może bowiem spowodować zniszczenie materiału niejawnego lub uniemożliwić odtworzenie informacji niejawnych w akredytowanym systemie informatycznym (przeznaczonym

48 B. Kunicka-Michalska, Przestępstwa przeciwko ochronie informacji..., s. 443.

49 M. Leciak, Tajemnica państwowa i jej ochrona, Toruń 2009, s. 219.

50 Tenże, Karnoprawna ochrona informacji..., s. 228.

${ }^{51}$ Zob. szerzej: B.J. Stefańska, Formy popetnienia przestępstwa, w: Kodeks karny. Komentarz, R. Stefański (red.), Warszawa 2015, s. 219 i nast.; K. Buchała, A. Zoll, Kodeks karny. Część ogólna, Kraków 1998, s. 84-88. 
do przetwarzania tajemnic). Wówczas, w ocenie autora artykułu, kumulatywna kwalifikacja czynu będzie obejmowała opcjonalnie popełnienie przestępstwa $\mathrm{z}$ art. $231 \mathrm{kk}$ w zbiegu $\mathrm{z}$ art. $268 \mathrm{kk}$ (268a kk) w związku z art. $2 \mathrm{kk}^{52}$ (przy założeniu, że nie dochodzi do ujawnienia lub wykorzystania informacji niejawnych ${ }^{53}$.

Analiza aktualnych przepisów karnych Federacji Rosyjskiej oraz Rzeczpospolitej Polskiej prowadzi do wniosku, że mimo początkowej jedności norm zakazu karnego w obu krajach system prawnokarnej ochrony informacji niejawnych (tajemnic) obowiązujący w Polsce jest mniej represyjny niż obowiązujący w Rosji. Na szczególną uwagę zasługuje art. $283^{1} \mathrm{kk}$ FR, który nie ma odpowiednika w polskim prawie karnym. Nie sprzyja to prewencji kryminalnej i zwalczaniu przestępstw groźnych dla bezpieczeństwa państwa. Niskie zagrożenie karą za popełnienie przestępstwa z art. 267 kk RP nie jest adekwatne do zagrożeń wynikających $\mathrm{z}$ nielegalnego uzyskiwania informacji ściśle tajnych czy tajnych, bez względu na ich późniejsze przeznaczenie przez sprawcę. Należy zatem postulować objęcie w przyszłości tego społecznie groźnego zachowania zakazem karnomaterialnym.

\section{Istotne elementy pozakodeksowego systemu ochrony tajemnic w Rosji}

Zarówno rosyjskie, jak i polskie przepisy karne penalizujące czyny, które naruszają bezpieczeństwo tajemnic, mają charakter blankietowy. Zdekodowanie norm zakazu karnego w celu ustalenia wypełniania znamion przestępstw może nastąpić wyłącznie dzięki zastosowaniu pojęć prawa federalnego, tj. ustawy o tajemnicy państwowej FR (ros. закон о государственной тайне, pis. fon. zakon o gosudarstwiennoj tajnie) $)^{54}$. W preambule do tej ustawy prawodawca stanowi, że reguluje ona stosunki, które powstają w związku

${ }^{52}$ Podjęte rozważania przekraczają ramy niniejszego artykułu, warto jednak dodać, że nie każde zaniechanie (niedopełnienie obowiązków), w którego wyniku następuje dokonanie przestępstwa skutkowego, np. zniszczenie materiału objętego tajemnicą, wypełnia znamiona przestępstwa. Jak trafnie zauważa Łukasz Pohl, „Nie każde niewykonane działanie jest działaniem zaniechanym” (Ł. Pohl, Zasady odpowiedzialności karnej..., s. 52). Zazwyczaj należy rozważyć trzy istotne aspekty: czy gwarant nienastąpienia skutku miał intelektualne możliwości oceny danej sytuacji, w której nie zapobiegł skutkowi, czy okoliczności występujące w miejscu i czasie, w których był zobowiązany podjąć działanie, spowodowały, że zaniechał tego działania i wreszcie, czy niemożność działania była spowodowana wcześniejszym wytworzeniem przez gwaranta takich przeszkód, które spowodowały zaniechanie $\mathrm{z}$ jego strony. Rozważenie tych kwestii wymaga zbadania dwóch aspektów: aspekt pierwszy - czy zaniechanie miało charakter wolicjonalny, aspekt drugi - czy wynikało ono z przyczyn niezależnych od sprawcy zaniechania albo przeszkód, których mimo podjęcia aktywności nie pokonał, co w rezultacie doprowadziło do nastąpienia skutku. Jak słusznie zauważa cytowany autor, nikt nie ma obowiązku czynienia rzeczy niemożliwych (łac. impossibilium nulla obligatio est - niemożliwe unicestwia obowiązek).

53 B. Kunicka-Michalska, Przestępstwa przeciwko ochronie informacji..., s. 619 i nast.; S. Hoc, Karnoprawna ochrona informacji, Opole 2009, s. 103 i nast.

54 Закон Российской Федерации от 21 июля 1993 г., No5485-1, „О государственной тайне” (Ustawa Federacji Rosyjskiej z 21 lipca 1993 r. nr 5485-1 „O tajemnicy państwowej”). 
z klasyfikacją informacji jako tajemnicy państwowej, utajnianiem i odtajnianiem informacji oraz ochroną informacji w celu zapewnienia bezpieczeństwa FR.

W artykule pierwszym wymienionej ustawy określono zakres jej stosowania według właściwości terytorialnej (obowiązuje na terytorium FR i poza jej granicami) oraz kompetencji podmiotowej. Adresatami ustawy są urzędnicy oraz obywatele, którzy przyjęli na siebie obowiązek przestrzegania jej postanowień albo co do których ten obowiązek wynika z ich statusu. Akt odnosi się dodatkowo do osób prawnych (instytucji), abstrakcyjnie zdefiniowanych jako: władze publiczne, samorząd terytorialny, przedsiębiorstwa, instytucje i organizacje - niezależnie od ich formy organizacyjnej oraz prawnej i stosunków własnościowych. Określenie właściwości podmiotowej przez rodzajowe wyliczenie osób i instytucji pozwala na stwierdzenie, że ustawa, o której mowa, nie ma zasięgu powszechnego, co jest zbieżne $\mathrm{z}$ odpowiednią regulacją $\mathrm{RP}$ (podmioty, do których jest adresowana Ustawa $z$ dnia 5 sierpnia 2010 r. o ochronie informacji niejawnych, zostały wyliczone w jej art. 1 ust 2).

Ważną wskazówką dotyczącą rozszerzenia obowiązywania ustawy o tajemnicy państwowej FR jest klauzula ustanowiona w art. 3, w którym rosyjski prawodawca nakazuje jej stosowanie odpowiednio do ustawy o bezpieczeństwie Federacji Rosyjskiej ${ }^{55}$ oraz innych ustaw, których przepisy dotyczą tajemnicy państwowej.

Definicje legalne pojęć użytych w ustawie zawiera art. 2. Z punktu widzenia odpowiedzialności karnej najistotniejsza jest definicja pojęcia „tajemnica państwowa”. Przez to pojęcie rozumie się informacje chronione przez państwo, dotyczące jego działań: wojskowych, międzynarodowych, gospodarczych, wywiadowczych, kontrwywiadowczych i operacyjno-rozpoznawczych. Rozpowszechnianie tych informacji może zaszkodzić bezpieczeństwu FR. Z tego wynika, że o uznaniu informacji z wymienionych dziedzin za tajemnicę przesądza kryterium groźby wystąpienia szkody. Zastosowana materialnoprawna konstrukcja definicji jest co do zasady zbieżna z polskim rozumieniem informacji niejawnych. Rosyjski prawodawca ustanowił wykaz informacji, które stanowią tajemnicę państwową, w art. 5 ustawy o tajemnicy państwowej i podzielił je według zagadnień wskazanych w przywołanej definicji.

Uzupełnieniem definicji pojęcia „tajemnica państwowa” i wykazu informacji stanowiących tego rodzaju tajemnicę, zawartego w art. 5 wymienionej ustawy, jest sporządzany przez Prezydenta FR spis dziedzin, z których informacje (z uwagi na ich charakter) stanowią tajemnicę państwową, oraz rejestr organów uprawnionych do zarządzania nimi. Od 1995 r. wykazy są publikowane łącznie w formie dekretu (ros. yкa3 Президента $Р \Phi$, pis. fon. ukaz Priezidienta RF $)^{56}$ i okresowo uzupełniane. Ostatnie zmiany wprowadzono 8 czerwca 2020 r. Aktualny dekret jest bardzo rozbudowany,

55 Федеральный закон от 28 декабря 2010, No 390-ФЗ, „О безопасности” (Ustawa federalna z 28 grudnia 2010 r. nr 390-FZ „O bezpieczeństwie”).

56 Указ Президента РФ от 30 ноября 1995 г., No 1203, „Об утверждении перечня сведений... (Dekret Prezydenta FR z 30 listopada 1995 r. nr 1203 „O zatwierdzeniu wykazu informacji...). 
wymienia m.in. następujące dziedziny i jednocześnie organy uprawnione do zarządzania informacjami, które funkcjonalnie są z nimi związane:

1) wojskowość - informacje dotyczące głównie: planów strategicznych, uzbrojenia, mobilizacji, gotowości i liczebności armii, użycia Sił Zbrojnych FR, operacji antyterrorystycznych, broni atomowej, programów naukowo-badawczych, łączności i częstotliwości radiowych, działań w kosmosie, międzynarodowej polityki w dziedzinie bezpieczeństwa (łącznie 28 szczegółowych obszarów); organy powiązane to: Ministerstwo Spraw Wewnętrznych, Ministerstwo Obrony FR, Ministerstwo Obrony Cywilnej, Federalna Agencja Rządowej Łączności i Informacji, Służba Graniczna Federalnej Służby Bezpieczeństwa FR, Rosatom ${ }^{57}$, Roskosmos ${ }^{58}$ i inne;

2) ekonomia, nauka i technologie (łącznie 40 szczegółowych dziedzin); organy powiązane to głównie ministerstwa: Obrony, Spraw Wewnętrznych, Rozwoju Cyfryzacji i Łączności oraz Komunikacji Masowej, Spraw Zagranicznych, Spraw Nadzwyczajnych, Transportu i in.;

3) polityka zagraniczna i gospodarka - informacje dotyczące głównie: strategii prowadzenia przez Rosję polityki zagranicznej między innymi w zakresie handlu paliwami, minerałami (metalami szlachetnymi) i bronią, umów dotyczących zbrojnego wsparcia innych państw, gospodarki finansowej (monetarnej), wywiadu, kontrwywiadu i czynności operacyjno-rozpoznawczych, sposobu ochrony i stanu tajemnic, kryptografii, finansowania wywiadu i kontrwywiadu, zwalczania obcych wywiadów i współpracy z nimi, danych personalnych własnej agentury i jej uplasowania w organach innych państw lub w zagranicznych grupach przestępczych, danych dotyczących rzeczywistego stanu i organizacji obrony oraz innych zagadnień (łącznie 45 rozbudowanych dziedzin); organy powiązane to: Służba Wywiadu Zagranicznego, Federalna Służba Kontroli Technicznej i Transportu, Ministerstwo Spraw Wewnętrznych, Ministerstwo Obrony FR, Ministerstwo Obrony Cywilnej, Federalna Agencja Rządowej Łączności i Informacji, Służba Graniczna Federalnej Służby Bezpieczeństwa FR, Federalna Służba Bezpieczeństwa, Służba Bezpieczeństwa Prezydenta FR, Główny Zarząd Bezpieczeństwa Ministerstwa Spraw Zagranicznych, Główny Zarząd ds. Operacji Specjalnych Prezydenta Rosji i inne.

Należy nadmienić, że dziedziny wymienione w dekrecie odpowiadają dziedzinom wskazanym w definicji tajemnicy państwowej, każda z nich jednak jest uszczegółowiona przez określenie kolejnych zagadnień tematycznych, którymi się zajmuje. W wyniku sprecyzowania dziedzin i podmiotów uprawnionych do zarządzania danego rodzaju informacjami istnieje możliwość dookreślenia odesłania zawartego w art. 29 ust. 4

57 Rosyjska Państwowa Korporacja Energii Atomowej „Rosatom”, https://rosatom.ru/about/ [dostęp: 30 VII 2020].

58 Rosyjska Państwowa Korporacja Rozwoju Technologii Kosmicznych „Roskosmos”, https://www. roscosmos.ru/25919/ [dostęp: 30 VII 2020]. 
Konstytucji FR oraz w art. 5 ustawy o tajemnicy państwowej. Warto zasygnalizować, że polskie prawodawstwo odeszło od konstruowania wykazów informacji stanowiących określoną tajemnicę wraz z wprowadzeniem do obrotu prawnego ustawy o ochronie informacji niejawnych z $2010 \mathrm{r}$.

Interesującym rozwiązaniem legislacyjnym zastosowanym w rosyjskiej ustawie jest określenie obowiązków i uprawnień najważniejszych organów państwa w zakresie ochrony, administrowania i oddziaływania na system prawny z uwagi na bezpieczeństwo tajemnic (art. 4). Organami zobowiązanymi są m.in. Prezydent FR (szczególnie do wydawania dekretów wykonawczych) oraz organy władzy sądowniczej, które rozpatrują sprawy karne, cywilne i administracyjne dotyczące naruszeń tajemnicy oraz mają zapewnić przestrzeganie tajemnicy we własnych strukturach.

Istotną regulacją, o której stanowi rosyjska ustawa, zbieżną w dużym zakresie z przepisami polskimi, jest nakaz klauzulowania informacji. Kryterium klasyfikacyjne tajemnicy wprowadza art. 8, wskazujący, że stopień klauzuli (poziom ochrony) powinien być adekwatny do rozmiaru szkody, jaką może ponieść FR w związku z rozpowszechnieniem (upublicznieniem) danej informacji. Należy zauważyć, że przepis stanowi o klauzulowaniu nośników informacji (a więc formy zmaterializowanej), a nie samej informacji, jak ma to miejsce w ustawie polskiej. Wspomniany przepis wprowadza trzy stopnie ochrony tajemnicy informacji, do których są przypisane klauzule tajności (ros. гриøы , pis. fon. grify): Особой важности (pol. „O szczególnym znaczeniu”), Совершенно секретно (pol. „Ściśle tajne”) і Секретно (pol. „Tajne”). Jednocześnie ustawodawca deleguje obowiązek uszczegółowienia zasad klasyfikowania informacji do danego stopnia tajności, tj. klauzuli, rządowi FR. Wprowadza również zakaz stosowania wymienionych klauzul do oznaczania informacji, które nie stanowią tajemnicy państwowej.

Warto nadmienić, że na podstawie umowy między rządem Rzeczpospolitej Polskiej a rządem Federacji Rosyjskiej o wzajemnej ochronie informacji strony zobowiązały się do wzajemnej ochrony informacji niejawnych wymienianych w wyniku współpracy politycznej, gospodarczej, naukowo-technicznej i innej ${ }^{59}$. Rządy określiły wzajemne przyporządkowanie stosowanych klauzul w celu zapewnienia otrzymywanym informacjom odpowiedniej ochrony.

\begin{tabular}{|c|c|c|}
\hline Lp. & Klauzula stosowana w RP & Klauzula stosowana w FR \\
\hline 1. & Ściśle tajne & Совершенно секретно \\
\hline 2. & Tajne & Секретно \\
\hline 3. & Poufne & Секретно \\
\hline 4. & Zastrzeżone & $\begin{array}{c}\text { Для служебного пользования } \\
\text { (рol. Do użytku służbowego) }\end{array}$ \\
\hline
\end{tabular}

59 Umowa między Rządem Rzeczypospolitej Polskiej a Rządem Federacji Rosyjskiej o wzajemnej ochronie informacji $z$ dnia 8 lutego 2008 r. (DzU z 2008 r. nr 217 poz. 1384). 
Na uwagę zasługuje przyporządkowanie polskich informacji poufnych i tajnych do rosyjskiej klauzuli „Секретно” oraz polskiej klauzuli „Zastrzeżone” do statusu rosyjskich informacji oznaczanych klauzulą „Для служебного пользования” („Do użytku służbowego"). W Polsce to ostatnie oznaczenie było stosowane przed wprowadzeniem ustawy o ochronie informacji niejawnych z 1999 r.

Ważnym faktem wynikającym z uzyskania przez daną osobę uprawnień dostępu do rosyjskiej tajemnicy państwowej jest wyrażenie przez nią zgody na ograniczenie jej wolności i praw obywatelskich. W art. 21 rosyjskiej ustawy o tajemnicy państwowej ustanowiono m.in. następujące ograniczenia i obowiązki:

1) złożenie pisemnego zobowiązania do nierozpowszechniania powierzonych informacji stanowiących tajemnicę państwową;

2) złożenie pisemnej zgody na przeprowadzenie procedury sprawdzającej przez organy państwowe według przepisów obowiązujących te podmioty;

3) wyrażenie zgody na częściowe, czasowe ograniczenie prawa: wyjazdu poza granicę państwa na uzgodniony okres, nienaruszalności życia prywatnego w związku z procedurą sprawdzającą i inne;

4) zapoznanie się z normami ustawodawstwa o tajemnicy państwowej, przewidującymi odpowiedzialność za ich naruszenie.

Warto wskazać, że jedynie deklaracja (pkt 2) i czynność (pkt 4) mają swoje odzwierciedlenie w przepisach polskiej ustawy o ochronie informacji niejawnych (podobne ograniczenia swobód wprowadzało Zarządzenie nr 60/83 Ministra Spraw Wewnętrznych z dnia 29 czerwca 1983 roku w sprawie szczegółowych zasad i sposobu postępowania $z$ wiadomościami stanowiącymi tajemnice państwowa i służbowa ${ }^{60}$ ).

Szczegółowym aktem, w którym określono procedurę i zakres czynności związanych $\mathrm{z}$ przeprowadzeniem postępowania sprawdzającego osób przez FSB, jest instrukcja dotycząca dopuszczenia urzędników i innych obywateli FR do tajemnicy państwowej. Została ona wprowadzona uchwałą rządu Federacji Rosyjskiej z 6 lutego 2010 r. ${ }^{61}$ Instrukcja zawiera szczegółowe regulacje, które usystematyzowano w sześciu działach:

1) Postanowienia ogólne;

2) Procedura formalnego uzyskania dostępu do tajemnicy państwowej;

3) Odstępstwa w procedurze uzyskania dostępu do tajemnicy państwowej dla osób pracujacych u kilku pracodawców;

${ }^{60}$ Archiwum Instytutu Pamięci Narodowej w Warszawie, Ministerstwo Spraw Wewnętrznych w Warszawie (1944) 1954-1990 (tytuł zbioru dokumentów - przyp. red.), sygn. IPN BU 01451/18, Zarzadzenie Ministra Spraw Wewnętrznych nr 60/83 z dnia 29 czerwca 1983 roku w sprawie szczegółowych zasad i sposobu postępowania $z$ wiadomościami stanowiącymi tajemnice państwowa i stużbowa, Warszawa 1983, (niepublikowane).

${ }_{61}$ Постановление Правительства РФ от 6 февраля 2010 г., $N^{\circ}$ 63, „Об утверждении Инструкиии о порядке допуска должностньх тии и граждан Российской Федерации к государственной тайне (Uchwała Rządu Federacji Rosyjskiej z 6 lutego 2010 r. nr 63 „O zatwierdzeniu instrukcji o procedurze dopuszczenia urzędników państwowych i obywateli Federacji Rosyjskiej do tajemnicy państwowej"). 
4) Odstępstwa w procedurze uzyskania dostępu do tajemnicy państwowej dla kierowników i członków organizacji samorzadowych ${ }^{62}$;

5) Powtórne uzyskanie dostępu do tajemnicy państwowej;

6) Procedura uzyskania dostępu do informacji stanowiących tajemnicę państwowa przez obywateli delegowanych do innych pracodawców.

W końcowej części instrukcji zamieszczono wzory formularzy ewidencyjnych przeznaczonych do: zaliczania stanowisk do określonego poziomu dostępu do tajemnicy; wnioskowania do FSB o przeprowadzenie postępowania sprawdzającego oraz późniejszej rejestracji osób, które uzyskały dostęp do tajemnicy; dokonywania zmian wynikających z utraty dostępu lub zmiany miejsca zatrudnienia oraz wzór ankiety personalnej.

Z postanowień zawartych w instrukcji wynika, że wykaz stanowisk związanych $\mathrm{z}$ dostępem do tajemnicy opracowuje szef komórki do spraw ochrony tajemnicy (ros. руководитель режимно-секретного подразделения) w porozumieniu ze swoim przełożonym, tj. kierownikiem danej instytucji. Następnie wykaz, o którym mowa, jest przesyłany w dwóch egzemplarzach do zatwierdzenia właściwej jednostce FSB. Po ewentualnym zatwierdzeniu jeden egzemplarz odsyła się do wytwórcy dokumentu. Wykaz jest aktualizowany co najmniej raz na pięć lat.

Wyróżnia się trzy poziomy dostępu do tajemnic: „szczególnego znaczenia”, „ściśle tajnych” i „tajnych”. Do poziomu informacji o klauzuli „Do użytku służbowego” nie przeprowadza się sprawdzeń ani odrębnej rejestracji, są one dostępne z uwagi na zajmowane stanowisko. Zainteresowany pracownik wypełnia ankietę, w której wskazuje ukończone szkoły, poprzednich pracodawców, miejsca zamieszkania i krewnych (powyżej 14 roku życia). Ponadto informuje o wyjazdach zagranicznych i podaje dane personalne osób, z którymi utrzymuje kontakty, a które wyjeżdżały poza FR lub są cudzoziemcami. Ankietę weryfikuje i podpisuje kierownik komórki do spraw kadrowych oraz kierownik komórki do spraw ochrony tajemnicy. Sprawdzeń danej osoby dokonuje się na wniosek kierownika komórki ochrony tajemnicy, skierowany do rejonowej jednostki FSB, która informuje o pozytywnym lub negatywnym wyniku sprawdzeń i nadaje indywidualny numer przyznanych uprawnień. Jeżeli kierownik jednostki organizacyjnej nie wyda decyzji o udostępnieniu osobie sprawdzonej informacji stanowiących tajemnicę państwową w okresie sześciu miesięcy, to procedurę sprawdzenia dokonanego przez FSB należy powtórzyć. Warto dodać, że objęcie dostępem do określonego poziomu tajemnicy nie ma charakteru uniwersalnego, jest ważne wyłącznie w instytucji (pracodawcy), która nadała uprawnienia. Na gruncie prawa polskiego poświadczenia bezpieczeństwa wydane przez Agencję Bezpieczeństwa Wewnętrznego albo Służbę Kontrwywiadu Wojskowego obowiązują we wszystkich innych podmiotach, wydane przez inne służby zaś

${ }^{62}$ W Federacji Rosyjskiej ustawowo powołano osoby prawne samoregulacyjne, które w dużym uproszczeniu zrzeszają producentów z danej branży w celu wspólnego podejmowania działań non profit (niekomercyjnych). Stanowi o tym rosyjska ustawa: Закон No 315-Ф3 от 1 декабря 2007 г. „О саморегулируемых организациях” (Ustawa nr 315-FZ z 1 grudnia 2007 r. „O samorządowych organizacjach zawodowych"). 
są ważne tylko w ich strukturach (art. 29 ust. 5 ustawy o ochronie informacji niejawnych). Jeżeli pracownik nie zmienia miejsca zatrudnienia, to powtórnego sprawdzenia (ros. обормление, tutaj w znaczeniu: 'rejestracja,' 'opracowanie') się nie dokonuje. Jeżeli natomiast pracownik zmienił pracodawcę, to - o ile nie wystąpiły przesłanki do cofnięcia przyznanego dostępu - powtórne sprawdzenie przeprowadza się po 10 latach w odniesieniu do tajemnic ściśle tajnych i po 15 - dla pozostałych. W instrukcji podano powody powtórnego sprawdzenia predyspozycji pracownika do ochrony powierzonych mu tajemnic. Jest to między innymi: zawarcie związku małżeńskiego (jeżeli małżonek również ma dostęp do tego typu informacji, sprawdzenia się nie przeprowadza), wyjazd za granicę na okres powyżej sześciu miesięcy, zatrudnienie w komórce do spraw ochrony tajemnicy państwowej albo zatrudnienie osoby, która wcześniej miała dostęp do określonych informacji na mocy prawa w związku ze sprawowaną funkcją (sędziowie, deputowani do Dumy Państwowej, członkowie Rady Federacji, adwokaci i obrońcy w sprawach karnych, w których wykorzystywano materiały chronione klauzulami).

Przesłanki, które wpływają na odmowę dostępu do informacji klauzulowanych lub na cofnięcie już przyznanych uprawnień, to:

1) całkowite lub częściowe ubezwłasnowolnienie;

2) oskarżenie o przestępstwo karne przeciwko władzy państwowej popełnione umyślnie lub z nieostrożności albo skazanie za to przestępstwo, a także niewykonanie nałożonej kary za tego rodzaju przestępstwa;

3) przeciwwskazania medyczne w zakresie dostępu do tajemnicy państwowej ${ }^{63}$;

4) pobyt sprawdzanego lub osób wymienionych w złożonej przez niego ankiecie za granicą (powyżej sześciu miesięcy) albo złożenie przez sprawdzanego lub osoby wymienione przez niego w ankiecie wniosku o zgodę na pobyt w innych krajach;

5) ustalenie w wyniku prowadzonych czynności sprawdzających okoliczności stwarzających zagrożenie bezpieczeństwa FR;

6) uchylanie się osoby sprawdzanej od współpracy w czynnościach weryfikacyjnych lub podanie fałszywych danych w ankiecie personalnej.

${ }^{63}$ Osoba, która ubiega się o dostęp do tajemnicy, jest zobowiązana przedstawić zaświadczenie o braku medycznych (psychicznych) przeciwwskazań do pracy z informacjami stanowiącymi tajemnicę państwową, wydawane na podstawie zarządzenia Ministerstwa Zdrowia i Rozwoju Społecznego FR, w: Приказ Министерства здравоохранения и социального развития РФ от 26 августа 2011 г., № 989н, „Об утверждении перечня медицинских противопоказаний для работы с использованием сведений, составляющих государственную тайну, порядка получения и формы справки об отсутствии медицинских противопоказаний для работь с использованием сведений, составляющих государственную тайну (Zarządzenie Ministerstwa Zdrowia i Rozwoju Społecznego FR z 26 sierpnia 2011 r., nr 989n, „O zatwierdzeniu wykazu przeciwwskazań lekarskich do pracy $z$ wykorzystaniem informacji stanowiacych tajemnicę państwowa, trybu uzyskiwania i formy zaświadczenia o braku przeciwwskazań lekarskich do pracy z informacjami stanowiącymi tajemnice państwową"). 
Jednostka FSB informuje kierownika danej instytucji o rezultacie sprawdzeń. Kierownik instytucji na tej podstawie podejmuje decyzję o udostępnieniu albo odmowie udostępnienia tajemnicy. Jeżeli decyzja jest negatywna, to osoba zainteresowana udostępnieniem informacji ma prawo wnieść skargę do organu wyższego stopnia w strukturach administracji publicznej albo wyższego przełożonego w pozostałych instytucjach, a następnie do sądu.

Warto nadmienić, że polska ustawa o ochronie informacji niejawnych z $2010 \mathrm{r}$. w odniesieniu do zdrowia psychicznego i uzależnień osób sprawdzanych uprawnia organ prowadzący poszerzone postępowanie sprawdzające do zobowiązania osoby sprawdzanej, aby poddała się odpowiednim badaniom i przedstawiła ich wyniki (art. 26 ust. 6 ustawy o ochronie informacji niejawnych). Ponadto w postępowaniu odwoławczym przed Wojewódzkim Sądem Administracyjnym sąd może, z urzędu lub na wniosek osoby sprawdzanej, skorzystać z uprawnień ustanowionych powyższym przepisem. W przypadku braku okoliczności wskazujących na istnienie schorzeń psychicznych lub uzależnień organ prowadzący postępowanie, co do zasady, przyjmuje na podstawie oświadczenia złożonego w ankiecie bezpieczeństwa, że dana osoba jest zdrowa. Rosyjskie regulacje nakazują złożenie zaświadczenia o braku przeciwwskazań zdrowotnych do pracy $\mathrm{z}$ informacjami stanowiącymi tajemnicę państwową $\mathrm{w}$ każdym przypadku wraz z wypełnioną ankietą.

Należy zasygnalizować, że instytucją prawną, która nie występuje w polskim prawodawstwie, są procentowe dodatki finansowe do uposażenia dla pracowników komórek ochrony tajemnicy oraz innych struktur - w zależności od poziomu dostępu do tajemnicy, ustanowione w art. 21 rosyjskiej ustawy o tajemnicy państwowej.

$\mathrm{W}$ przypadku podjęcia przez pracownika równoległej pracy $\mathrm{w}$ innym podmiocie na stanowisku z dostępem do tajemnicy państwowej pracodawca wydaje duplikat decyzji o dopuszczeniu go do określonego poziomu tajemnicy. Jednocześnie przesyła do rejonowej jednostki FSB kartę ewidencyjną z informacją o przekazaniu uprawnień do innego pracodawcy oraz informuje drugiego pracodawcę o jednostce FSB, która przeprowadziła czynności sprawdzające, i podaje numer oraz datę wydania tych uprawnień.

Gdy kierownik danej instytucji otrzyma od FSB informacje dotyczące okoliczności, które mogą stanowić podstawę cofnięcia określonemu pracownikowi dostępu do tajemnicy państwowej, podejmuje decyzję w tej sprawie. Jeżeli postanawia utrzymać dotychczasowe uprawnienia $\mathrm{w}$ zakresie dostępu do tego rodzaju tajemnicy w kierowanym przez niego podmiocie, pisemnie informuje jednostkę FSB o powodach uzasadniających to utrzymanie wbrew informacji organu bezpieczeństwa.

W związku z istotną rolą FSB w reglamentacji publicznoprawnych tajemnic FR należy odnieść się do zadań tej formacji ${ }^{64}$. Uprawnienia i obowiązki jej żołnierzy oraz pracowników są bardzo szerokie i wynikają z uniwersalnego charakteru służby. Zakres oddziaływania FSB na system bezpieczeństwa państwa jest nieporównywalny

64 Федеральный закон от 3 апреля 1995 г., № 40-Ф3, „О Федеральной службе безопасности”... (Ustawa federalna z 3 kwietnia 1995 r. nr 40-FZ „O Federalnej Stużbie Bezpieczeństwa”...). 
z zakresem oddziaływania jakiejkolwiek ze służb polskich. Ustawowe zadania tej formacji obejmują: walkę z terroryzmem i przestępczością, ochronę granicy państwowej, a przede wszystkim - prowadzenie wojskowego i cywilnego kontrwywiadu oraz wywiadu we współpracy ze Służbą Wywiadu Zagranicznego FR (ros. Служба Внешней Разведки - CBP, pis. fon. Służba Wnieszniej Razwiedki - SWR; przed 1991 r. - Zarząd I KGB ZSRR. Dalej będzie stosowany skrót najbardziej rozpoznawalny w Polsce: SWR $)^{65}$. Ważnym zadaniem SWR z punktu widzenia bezpieczeństwa informacji jest prowadzenie rozpoznania osób, które uzyskały dostęp do tajemnicy państwowej FR i przebywają poza granicami tego kraju (art. 11 ustawy o SWR). W odniesieniu do FSB natomiast należy zaznaczyć, że jednym z aspektów działalności kontrwywiadowczej tej służby jest ochrona tajemnicy państwowej (art. 9 pkt w oraz art. 12 pkt k ustawy o FSB). Powyższe zadanie jest realizowane przez:

1) partycypację w opracowywaniu i wdrażaniu środków ochrony informacji stanowiących tajemnicę państwową;

2) sprawowanie kontroli nad zapewnianiem bezpieczeństwa informacji stanowiących tajemnicę państwową w organach państwowych, formacjach wojskowych, przedsiębiorstwach, instytucjach i organizacjach, niezależnie od formy własności;

3) przeprowadzanie, według ustalonej procedury, działań związanych z udostępnianiem informacji stanowiących tajemnicę państwową.

Dodatkowo zadania FSB i sposób ich realizacji, m.in. w odniesieniu do ochrony tajemnicy państwowej, zostały uszczegółowione w pkt 9 ppkt 12 dekretu Prezydenta FR z 2003 r. w sprawie zadań FSB ${ }^{66}$. Zgodnie z tym aktem służba przeprowadza czynności w zakresie udzielania obywatelom i osobom prawnym dostępu do tajemnicy państwowej.

Ważną instrukcją kształtującą system ochrony tajemnicy państwowej w FR jest instrukcja o zabezpieczaniu zachowania tej tajemnicy. W związku z tym, że wydano ją z klauzulą „Do użytku służbowego”, nie została ona opublikowana ${ }^{67}$. Merytoryczne zbadanie i omówienie metod i środków stosowanych przez FSB w celu ochrony tajemnicy państwowej napotyka poważne trudności ze względu na ustawowy obowiązek chronienia tego rodzaju informacji, a w rezultacie - objęcie ich tajemnicą.

Niniejszy artykuł nie wyczerpuje przedmiotu rozważań, może jednak stanowić podstawę wstępnych wniosków, a także asumpt do dalszych badań.

65 Федеральный закон от 10 января 1996 г., $N^{\circ}$ 5-ФЗ, „О внешней разведке” (Ustawa federalna z 10 stycznia 1996 r. nr 5-FZ „O wywiadzie zagranicznym”).

66 Указ Президента РФ от 11 августа 2003 г., $N^{\circ}$ 960, „Вопросы Федеральной службы безопасности Российской Федерации” (Dekret Prezydenta FR z 11 sierpnia 2003 r. nr 960 „Zadania Federalnej Służby Bezpieczeństwa Federacji Rosyjskiej”).

67 Постановление Правительства Российской Федерации от 5 января 2004 2., $N^{\circ}$ 3-1, „Об утверждении Инструкиии по обеспечению режима секретности в Российской Федерации” (Uchwała z dnia 5 stycznia 2004 r. Rządu Federacji Rosyjskiej nr 3-1 „O zatwierdzeniu Instrukcji o zabezpieczeniu zachowania tajemnicy w Federacji Rosyjskiej”). 


\section{Podsumowanie}

Należy stwierdzić, że polski system ochrony najistotniejszych tajemnic publicznoprawnych ustanowiono aktami prawa administracyjnego $\mathrm{z}$ uwzględnieniem dziedzin określonych w art. 61 ust. 3 Konstytucji RP. Naruszenie ich poufności, które może zagrozić interesowi państwa, jest sankcjonowane prawem karnym. Podobne konstrukcje prawne przyjęto w prawodawstwie Federacji Rosyjskiej. Uregulowanie systemu ochrony tajemnic państwowych, w tym zasad weryfikacji osób aktami prawa administracyjnego, a także blankietowy charakter przepisów karnego prawa materialnego FR, pozwalają na identyfikację podobnych elementów w polskim systemie ochrony informacji niejawnych. Wyraźne podobieństwa regulacji zachodzą w odniesieniu do przepisów uchylonego polskiego kodeksu karnego z 1969 r. oraz ustawy o ochronie informacji niejawnych z 1999 r. Aktualne prawodawstwo RP wprowadza uniwersalne kryteria klasyfikowania informacji i obejmowania ich ochroną państwa. Zrezygnowano ze sporządzania wykazów informacji, którym należy nadać klauzulę. Pozwala to na zidentyfikowanie różnic w systemie ochrony informacji niejawnych (tajemnic państwowych) Polski i Rosji, a ponieważ nie są one diametralne, przyjęta na wstępie hipoteza robocza zostaje obalona.

\section{Bibliografia}

Andrejew I., Polskie prawo karne w zarysie, Warszawa 1989, Państwowe Wydawnictwo Naukowe.

Bosiacki A., Izdebski H., Konstytucjonalizm rosyjski. Historia i współczesność, Kraków 2013, Wydawnictwo ARCANA.

Dębski R., Pozaustawowe znamiona przestępstwa, Łódź 1995, Wydawnictwo Uniwersytetu Łódzkiego.

Hoc S., Karnoprawna ochrona informacji, Opole 2009, Wydawnictwo Uniwersytetu Opolskiego.

Kunicka-Michalska B., Przestępstwa przeciwko ochronie informacji i wymiarowi sprawiedliwości, Warszawa 2000, C.H. Beck.

Leciak M., Karnoprawna ochrona informacji niejawnych, Toruń 2012, TNOiK.

Leciak M., Tajemnica państwowa i jej ochrona, Toruń 2009, TNOiK.

Marek A., Prawo karne, Warszawa 2016, C.H. Beck.

Pohl Ł., Zasady odpowiedzialności karnej, w: Kodeks karny. Komentarz, R. Stefański (red.), Warszawa 2015, C.H. Beck. 


\section{Literatura rosyjska}

Борисов А.Б., Комментарий к конституции Российской Федерации (постатейный): с комментариями Конституционного суда РФ, Москва 2013, Книжный мир.

Борисов А.Б., Комментарий к Уголовному кодексу Российской Федерации (постатейньй) с постатейными материалами и практическими разбяснениями офиииальных органов, wyd. 7, Москва 2014, Книжный мир.

Лебедев В.М., Уголовный кодекс Российской Федераиии с научно-практическими комментариями, Варшава 1997, Бюро по демократическим институтам и правам человека.

Пудовочкин Ю.Е., Преступления против государственной власти, в: Комментарий к Уголовному кодексу Российской Федерации, t. 2, А.В. Бриллиантов (red.), Москва 2017, Проспект.

Скоробогатова О.О., Перчаткина С.А., Уголовный кодекс Российской Федерации с комментариями, Москва 2012, Эксмо.

Юридический энциклопедический словарь, А.В. Малько (red.), wyd. 2, Москва 2017, Проспект.

\section{Akty prawne}

Konstytucja Rzeczypospolitej Polskiej z dnia 2 kwietnia 1997 r. uchwalona przez Zgromadzenie Narodowe $w$ dniu 2 kwietnia 1997 r., przyjęta przez Naród w referendum konstytucyjnym w dniu 25 maja 1997 r., podpisana przez Prezydenta Rzeczypospolitej Polskiej w dniu 16 lipca 1997 r. (DzU z 1997 r. nr 78 poz. 483).

Umowa między Rządem Rzeczypospolitej Polskiej a Rządem Federacji Rosyjskiej o wzajemnej ochronie informacji z dnia 8 lutego 2008 r. (DzU z 2008 r. nr 217 poz. 1384).

Ustawa $z$ dnia 5 sierpnia 2010 r. o ochronie informacji niejawnych (t.j.: DzU z 2019 r. poz. 742).

Ustawa $z$ dnia 29 sierpnia 2002 r. o stanie wojennym oraz o kompetencjach Naczelnego Dowódcy Sit Zbrojnych i zasadach podległości konstytucyjnym organom Rzeczypospolitej Polskiej (t.j.: DzU z 2017 r. poz. 1932).

Ustawa z dnia 6 września 2001 r. o dostępie do informacji publicznej (t.j.: DzU z 2020 r. poz. 2176).

Ustawa z dnia 14 grudnia 1982 r. o ochronie tajemnicy państwowej i służbowej (DzU z 1982 r. nr 40 poz. 271, ze zm.). 
Rozporządzenie Prezydenta Rzeczypospolitej z dnia 24 października 1934 r. o niektórych przestępstwach przeciwko bezpieczeństwu Państwa (DzU z 1934 r. nr 94 poz. 851).

Rozporzadzenie Prezydenta Rzeczypospolitej z dnia 16 lutego 1928 r. o karach za szpiegostwo i niektóre inne przestępstwa przeciw Państwu (DzU z 1928 r. nr 18 poz. 160).

Dekret z dnia 26 października 1949 r. o ochronie tajemnicy państwowej i służbowej (DzU z 1949 r. nr 55 poz. 437).

Dekret z dnia 13 czerwca 1946 r. o przestępstwach szczególnie niebezpiecznych w okresie odbudowy Państwa (DzU z 1946 r. nr 30 poz. 192).

Dekret z dnia 16 listopada 1945 r. o przestępstwach szczególnie niebezpiecznych w okresie odbudowy Państwa (DzU z 1945 r. nr 53 poz. 300).

\section{Rosyjskie akty prawne}

Конституиия Российской Федерации от 12 декабря 1993 г., https://rg.ru/zakon/1993/12/25_ publish.html [dostęp: 8 II 2021].

Указ Президента РФ от 30 ноября 1995 г., № 1203, „Об утверждении перечня сведений, отнесенных к государственной тайне”, http://base.garant.ru/10105548/ [dostęp: 19 I 2021].

Федеральный закон от 8 марта 2015 г., № 21-Ф3, „Кодекс административного судопроизводства Российской Федерации”, https:/fzrf.su/kodeks/kas/ [dostęp: 8 II 2021].

Федеральный закон от 30 декабря 2001 г., No 195-Ф3, „Кодекс Российской Федераиии об административных правонарушениях", https:/fzrf.su/kodeks/koap/ [dostęp: 8 II 2021].

Федеральный закон о безопасности от 28 декабря 2010 г., № 390-ФЗ, „О безопасности”, https://fzrf.su/zakon/o-bezopasnosti-390-fz/ [dostęp: 8 II 2021].

Федеральный закон от 9 февраля 2009 г., № 8-Ф3, „Об обеспечении доступа к информации о деятельности государственных органов и органов местного самоуправления", http://www.consultant.ru/document/cons_doc_LAW_84602/ [dostęp: 8 II 2021].

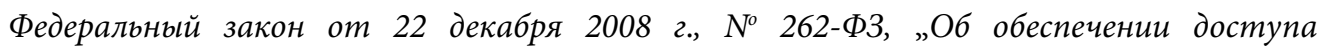
к информации о деятельности судов в Российской Федерации”, https:/fzrf.su/zakon/ dostup-k-informacii-o-deyatelnosti-sudov-262-fz/ [dostęp: 8 II 2021].

Федеральный закон от 2 мая 2006 г., № 59-Ф3, „О порядке рассмотрения обращений граждан Российской Федерации”, http://www.consultant.ru/document/cons_doc_LAW_ 59999/ [dostęp: 8 II 2021]. 
Федеральньй закон от 17 января 1992 г., $N^{\circ}$ 2202-1, „О прокуратуре Российской Федерации”, https://fzrf.su/zakon/o-prokurature-2202-1/ [dostęp: 8 II 2021].

Закон Российской Федерации от 21 июля 1993 г., № 5485-1, „О государственной тайне”, с изменениями, Законодательство Российской Федерации, Сборник основных федеральных законов РФ, http://fzrf.su/zakon/o-gosudarstvennoj-tajne-n-5485-1/ [dostęp: 30 VII 2020].

Уголовный кодекс Российской Федерации от 13 июня 1996 г., № 63-Ф3, с изменениями, Законодательство Российской Федерации, Сборник основных федеральных законов РФ, https://fzrf.su/kodeks/uk/ [dostęp: 8 II 2021].

Постановление Конституизионного Суда РФ от 20 декабря 1995 г., No 17-П, по делу о проверке конституционности ряда положений пункта „а” статьи 64 Уголовного кодекса РСФСР в связи с жалобой гражданина В.А. Смирнова, http://legalacts.ru/doc/ postanovlenie-konstitutsionnogo-suda-rf-ot-20121995-n/ [dostęp: 30 VII 2020].

Постановление Правительства РФ от 6 февраля 2010 г., $N^{\circ}$ 63, „Об утверждении Инструкиии о порядке допуска должностных лии, и граждан Российской Федераици к государственной тайне”, http://www.consultant.ru/document/cons_doc_LAW_ 97474/ [dostęp: 8 II 2021].

\begin{abstract}
Abstrakt
W artykule omówiono regulacje administracyjne dotyczące udostępniania informacji tajnych i ściśle tajnych oraz przedstawiono przepisy karne dotyczące ujawniania tajemnicy państwowej obowiązujące w Federacji Rosyjskiej wraz z ich interpretacją. Autor w odniesieniu do rosyjskich przepisów konstytucyjnych, administracyjnych i karnych wybiórczo przedstawia adekwatne do nich przepisy prawa polskiego. Ponadto w związku z tym, że przepisy prawa karnego nie zawierają definicji terminów użytych do ich konstrukcji, w artykule zaprezentowano przepisy administracyjne rosyjskiego systemu ochrony tajemnic publicznych, które są niezbędne do rekonstrukcji karnych norm prawnych. Na podstawie opracowania sformułowano wniosek, że w polskim ustawodawstwie brakuje odrębnego przepisu penalizującego uzyskanie informacji tajnej lub ściśle tajnej w wyniku popełnienia odrębnego czynu zabronionego. Powyższe może być podstawą do ewentualnych przyszłych zmian legislacyjnych w tym zakresie.

Należy zaznaczyć, że artykuł nie wyczerpuje tematu, a jedynie wskazuje wybrane zagadnienia związane $\mathrm{z}$ systemem ochrony tajemnicy państwowej w Rosji. Zainicjowana eksploracja może w przyszłości być wykorzystana do pogłębionych badań porównawczych nad zagadnieniem, o którym mowa.
\end{abstract}

Słowa kluczowe: służba specjalna, kodeks karny, ujawnienie, informacje niejawne, postępowanie sprawdzające, poświadczenie bezpieczeństwa. 


\title{
The protection of State Secrets in the Russian Federation. Selected penal and administrative regulations
}

\begin{abstract}
The article discusses the administrative regulations regarding the disclosure of secret and top-secret information in the Russian Federation. Moreover, it presents the effective penal code provisions directed against the disclosure of state secrets in Russia and the interpretation of these provisions. The author does not limit himself only to Russian constitutional, administrative and criminal regulations but gives examples of Polish corresponding laws. Additionally, in connection with the fact that criminal law provisions often contain non-specific references to other legislation, the article presents administrative acts of the protection system of public secrets. On the basis of the formulated conclusions, it was recognised that the Polish legislation lacks an individual provision penalising the fact of obtaining secret or top-secret information as a result of committing a separate unlawful act. It can be the basis to formulate postulates de lege ferenda.

It should be noted that the article does not exhaust the topic, but only indicates selected issues of the protection system of state secrets in Russia. Initiated study can be used to carry out in-depth comparative research on this topic in the future.
\end{abstract}

Keywords: secret service, penal code, disclosure, classified information, security background investigation, security clearance. 